Article

\title{
Financial Spillover Effects in Supply Chains: Do Customers and Suppliers Really Benefit?
}

\author{
Erik Hofmann *(1) and Yannick Sertori ${ }^{\circ}$ \\ Institute of Supply Chain Management, University of St. Gallen, 9000 St. Gallen, Switzerland; \\ yannick.sertori@gmail.com \\ * Correspondence: erik.hofmann@unisg.ch
}

Received: 2 February 2020; Accepted: 4 March 2020; Published: 10 March 2020

check for updates

\begin{abstract}
Studies have shown that leading supply chain companies are associated with significantly higher company financial ratios than competitors. In contrast, little research has focused on the financial performance of the affiliated suppliers and customers of such supply chain leader (SCL) companies. Thus, the central purpose of this paper is to determine, from a financial perspective, whether suppliers and customers benefit or lose by participating in a SCL network (so called "financial spillover effects"). Companies that were ranked in the Gartner Supply Chain Top 25 were selected as SCLs. For each selected firm, the five largest suppliers and customers were identified and compared with a control sample from the same industry. In order to elaborate on existing insights into the (financial) outcome of supply chain relationships, we applied an explorative approach with abductive reasoning, while comparing the secondary data for 224 SCL supplier (56 firms) and 168 SCL customer (42 firms) firm-years with 1940 (485 firms) and 1544 (386 firms) control firm-years, respectively. The following insights are made: First, the superior financial performance of SCLs was confirmed. Second, the financial performance of suppliers and customers showed superior liquidity and activity ratios but inferior profitability ratios. Third, suppliers showed much more significant results than customers.
\end{abstract}

Keywords: financial performance; supply chain excellence; supply chain relationship; supply chain finance; liquidity redistribution; profitability waiver; Wilcoxon signed rank test

\section{Introduction}

"Firms do not survive and prosper, solely through their own individual efforts, as each firm's performance depends in important ways on the activities and performance of others and hence on the nature and quality of the direct and indirect relations a firm develops with these counterparts" [1] (p. 123). This dependency between companies implies that relationships among companies are of increasing importance today. As various research papers indicate, company relationships based on collaboration are linked to higher performance [2-6]. In recent years, consensus has emerged that competition in the market has shifted from firm against firm to supply chain against supply chain [7-10]. Therefore, supply chain management (SCM) has greatly increased in importance and with supply chains, today is seen as a potential source of competitive advantage [11-13]. Many studies have shown that excellent SCM practices generate an increase in financial performance [11,13-17]. However, although many researchers have come to comparable conclusions, each study was carried out in different ways and analyzed financial performance with different measures [10]. Although one group of researchers used accounting-based measures [11,13,16], another group used market-based measures [18], or a combination of both [14,17]. While most of these studies tried to differentiate between more and less successful firms, some investigations used established rankings. For instance, Greer and Theuri [15] applied Gartner's (formerly AMR) Supply Chain Top 25 ranking, in order to 
link SCM superiority to multifaceted firm financial performance. The authors showed the superior financial performance of these supply chain leaders (SCLs). However, within their analysis, Greer and Theuri [15] neglected to examine the impacts on the affiliated supply chain business partners of these leading companies. Do the affiliated suppliers and customers of these SCLs benefit to the same extent, or is the success of the SCLs, in contrast, based on the exploitation of their market position? In a more generalized way, Crook and Combs [19] pointed out that today there is consensus on the positive influence of effective SCM on firms' performance, but less attention is given to the distribution of the gains through a supply chain. It is interesting to understand whether other members in an "outperforming" supply chain derive benefit from this kind of leadership, too, and, if so, how. Thus, we try to close this gap by focusing on suppliers and customers of SCLs and analyzing their (accounting-based) financial performance. We call such a financial reaction in the supply chain a "financial spillover effect".

The question of whether and how affiliated suppliers and customers benefit from leading supply chain companies is mainly discussed with the topic of supply chain relationships. In that sense, Kim and Henderson [20] classified supply chain relationships as of either a competitive (associated with power) or cooperative (associated with embeddedness) nature. Commonly, studies in the context of power relations have analyzed the dominant position of buying companies (customers) and highlighted a negative impact on suppliers' financial performance [21-23], especially a negative effect on profitability [24]. Even confronted with powerful customers, in some cases, suppliers have also been associated with positive returns in terms of liquidity ratios, such as shorter cash conversion cycles [25]. Contrarily, studies analyzing the cooperative nature of supply chain relationships use different-often non-financial-performance data [26,27], making a comparison difficult. Cooperative-dominant studies even focus on the affiliated suppliers' or buyers' operational performance improvements or efficiency effects [27-30]. Thus, there has only been limited comprehensive analysis in the literature of the financial performance implications for the affiliated suppliers and customers of leading supply chain firms [21,22,31]. Herein, "comprehensively" means an impact analysis in terms of liquidity, financial activity and profitability measures.

Based on these gaps, the present study tries to answer the following research question: "Do suppliers and customers of SCLs demonstrate superior financial ratios compared to those of other companies from the same industry?" The purpose of this study is to investigate the financial spillover effect in supply chains and whether suppliers and customers may derive beneficial advantages from participating in an SCL's network. The study is carried out by selecting firms from the three central samples (SCLs, SCL suppliers and SCL customers). We collect financial statement information about SCLs' key customers and suppliers. The control samples are established by taking firms from the same industry. The analysis is based on secondary data (financial ratios). The usage of secondary data to build or elaborate theory is common in finance research. This is also becoming increasingly common in supply chain and industrial organization research, as suggested by Rabinovich and Cheon [32] and Busse [33]. We assume that publicly available practices-affiliation with a certain supply chain network - can explain variations in firm-level (financial) performance. Based on Gartner's Supply Chain Top 25 ranking, we identified a set of SCLs. A Wilcoxon signed rank test was conducted. Following an explorative study approach with abductive reasoning, we identify some interesting correlations and state propositions at the end.

This study shows that suppliers and customers are associated, on one hand, with superior liquidity and activity and, on the other, with inferior profitability ratios compared with peers from the same industry. These findings confirm the existence of financial spillover effects in supply chains, highlighting correlations between supplier and customer ratios and demonstrating that SCLs' business partners can derive financial performance benefits (and losses) from their participation in an SCL network. In accordance with Kim and Henderson [20], it is suggested that in such supplier-customer relations, competitive and cooperative relationships co-exist. The present findings also contribute to the work of Gulati and Sytch [28] who, in relation to interdependency, distinguished between 
asymmetry dependency (in terms of the logic of power) and joint dependency (in terms of the logic of embeddedness). The contribution for practitioners is a profound understanding of the potential consequences of participating in an SCL's network. Nevertheless, this topic warrants further exploration in future studies.

This paper is organized as follows: In Section 2, the theory and a literature review about the central topics are provided. In Section 3, the methodology is presented, explaining the explorative study approach with abductive reasoning, data sources, sample selection and data analysis methods. In Section 4, the results for each of the three samples are highlighted separately. In Section 5, the findings are discussed, and propositions are put forward. Finally, in Section 6, a conclusion is given, as well as implications for theory, practice and future research.

\section{Research Context}

\subsection{Supply Chain Management and Firm Financial Performance}

Johnson and Templar [34] state that SCM "directly impacts organizational profitability, liquidity and productivity and the effects can be measured and reported via the financial statements and ratios used to externally monitor organizational performance" (p. 91). In practice, the Pricewaterhouse Coopers Global Supply Chain Survey 2013 came up with six key findings about how leader firms manage supply chains. One of these findings is that improving a company's supply chain leads to around $70 \%$ higher financial and operational performance [35]. In addition, Deloitte Consulting LLP [36] (p. 2), in their 2014 Global Supply Chain Survey, which selected leader and follower companies, showed that the majority of SCLs demonstrate well above average revenue growth and earnings before interest and taxes (EBIT) margins. In this study, leaders and followers were selected by questioning a large number of executives (more than 400) in manufacturing and retail firms about distinctive supply chain approaches and by using two performance metrics (inventory turnover and percentage of deliveries that are on time and in full) [36] (p. 1).

The link between the efficiency of supply chain processes and financial performance, which finally improves value for shareholders, has been established in the literature [37-39]. Christopher [40] depicted the three main financial dimensions of a firm that are influenced by SCM: cash flow, profit and resource utilization. A firm's profitability depends to a large extent on how costs are managed in a supply chain [41]. An increase in supply chain efficiency, which reduces costs, increases a company's short-term profit [42]. To calculate cost efficiency, the cost to sales (cost of goods sold (COGS) to sales) ratio is a commonly used metric [43]. In terms of liquidity, the cash conversion cycle is a metric for measuring the net cash flow generated from a firm's assets [44]. In literature, it is also named cash-to-cash [45], cash cycle [24] or net operating cycle [46]. For the purpose of uniformity during the study, the name cash conversion cycle (CCC) will be used. A reduction in inventory and accounts receivable and an extension of accounts payable are the drivers for improving the CCC financial ratio.

The literature on the financial impacts of SCM performance can roughly be clustered into two groups [10]: supply chain excellence and supply chain disruptions. While the first group of literature analyzes the contribution of exemplary SCM practices [11,14-17,47], the second group focuses on supply chain disruptions and their negative financial impact [48-50]. For the present analysis, the first group is of greater interest and is further examined.

D'Avanzo et al. [14] showed that leader firms, compared with the industry average growth rate, are associated with significantly higher market capitalization growth rates. In this study, leaders were selected through "a statistical correlation between companies' financial success and the depth and sophistication of their supply chains" (p. 40). The leading companies were found through different sources, including, among others, the Gartner Supply Chain Top 25 ranking [51]. Whereas Ellinger et al. [11] showed that leading companies have a higher Altman Z-score compared to their peers, Greer and Theuri [15] found that SCLs outperform non-SCL competitors in terms of accounting-based costs, activity and liquidity ratios, proving that SCLs are financially healthier. Swink et al. [17] showed 
that leading companies in SCM, compared to competitors, are associated with significantly better financial and market metrics.

Regarding the financial strength of the SCLs, two other issues are combined. First, the question arises from where the better financial and market metrics come. Second, it is of interest what happens with these financial resources (retention vs. disbursement). The SCM literature provides various theoretical explanations for both points.

Regarding the first point (the source of superior financial metrics), two different perspectives are to be distinguished. A positive "success" was realized based on their own strength, including the unilateral exploitation of an asymmetrical power situation [28], which amounts to the temptation to pursue opportunistic behavior [52]. If this is the dominant point of view, it is not expected that related suppliers and customers will profit to the same extent [53]. In contrast, an argument can also be made for the joint activities in the supply chain as the reason for the positive success. A possible explanation can be found in the relational exchange and the related joint learning and knowledge transfer approach $[54,55]$. The joint dependency approach also contributes to this [28]. Gulati and Sytch [28] found that while joint dependency improves the performance of manufacturers in procurement relationships, this effect is partially moderated "by the level of joint action and the quality of information exchange between the partners" (p. 32). Especially in long-term relationships, the supply chain efficiency improves [56], and the performance of key suppliers increases [57].

Regarding the use of the financial resources, there are again two possible approaches. Initially, the resources could stay in the company as profit retention, or they could be distributed to own shareholders (both leading to a negative spillover effect). Furthermore, an additional possible explanation could be found in the supply chain-oriented interpretation of the resources dependence theory, in which the supply chain members recognize that dependence can create forbearance and trust [58]. In such a model, SCL-related suppliers and customers would positively profit though an inter-organizational redistribution of financial resources in the supply chain.

Regarding these issues, research gaps arise as the perspectives predominantly applies to SCLs has not yet been completely clarified. Furthermore, it is unclear to what extent the considerations between the categories of financial figures differ. It is quite possible that the attitude of SCLs differs regarding the provision of liquidity compared to profit sharing.

\subsection{Supplier and Customer Performance Implications from Supply Chain Relationships}

As Tan et al. [59] (p. 1047) point out, companies today cannot exist in isolation, and for this reason, the integration of suppliers with their customers, as well as customers with their suppliers, is central to achieve, among other indicators, financial goals. This fact leads to the question of what exactly the benefits are for suppliers and customers in supply chains.

To date, different studies have explored the benefits for different actors operating in supply chains. It is striking how many ways the researchers who have investigated this topic differ, in areas such as industry focus and/or the element of SCM that is analyzed, such as total quality management (TQM) [59,60], efficient consumer response [61] or information technology [31]. Moreover, central to this academic field is the analysis of the benefits that can be drawn from different relationships between actors in supply chains. Various studies, among others, have analyzed the performance effects of supply chain relationships. Whereas research concerned with supply chain relationships differs in the analysis of the members in a relationship (e.g., supplier-manufacturer [21] or supplier-retailer [28]), the literature on the benefits of suppliers and customers in supply chains has come to different results and conclusions. Kim and Henderson [20] categorize the existing literature on supply chain relationships as being of either a competitive or cooperative nature.

Although competitive relationships are often analyzed in power situations, the cooperative viewpoint focuses on embeddedness. Deepening the study's findings related to power contexts, Kim and Wemmerlöv [23] found that customer power, created by the supplier's dependency, is positively associated with increasing cooperation, which has a negative impact on the supplier's financial 
performance. By analyzing the relationship between suppliers and main customers, Patatoukas [25] has shown that the buyer's power has a negative effect on the supplier's profitability by reducing the gross margin and has a positive influence by reducing selling, general and administrative expenses (SG\&A), enhancing asset utilization and shortening the CCC. Through an examination of supplier-seller-buyer relationships, Lanier et al. [24] suggest that, whereas profitability in supply chain relationships is more likely to be sourced from downstream supply chain partners, CCC benefits are gained by every member in the chain. Furthermore, Gosman and Kohlbeck [21] analyzed the consolidation in the retail market. They concluded that the increase in bargaining power for retailers decreased suppliers' gross margin. Confirming these results, other studies proved that customer concentration and power increase the dependency of suppliers [62] and decrease suppliers' profitability [22]. Furthermore, in line with Duffy and Fearne [63], the literature shows that power asymmetry can have a negative impact on the distribution of benefits in supply chain partnerships.

Although powerful buyers have a negative impact on a supplier's performance, and especially on profitability [21], in some cases, suppliers are also associated with positive returns in liquidity ratios, such as a shorter CCC $[24,25]$. A question that arises in connection with the power asymmetry and the supposed dependency of suppliers from their customers and of customers from their suppliers is about the reasons that lead to this situation, particularly as it involves a more or less exposed SCL. According to the strategic choice approach, from a supplier's perspective, it could have been a conscious decision based on the attractiveness of winning the SCL as a customer. The attractiveness of the SCL, from the supplier's perspective, can be based upon its brand strength or its reputation or due to its size and the related market potential. Within an existing supplier-buyer relationship, the degree of dependence varies depending on how much a creditor can afford to lose [64]. In order to acquire the SCL as a customer, the suppliers can make a specific investment (e.g., implementation of a specific IT system or adaptation of processes). Such investments or the acceptance of a discount on their sales lead to a reduction in the supplier's profitability.

A similar argumentation can be made from the perspective of a SCL customer. Studies suggest that a retailer's (customer's) ability to partner with focal suppliers (SCLs) is key to category management effort and performance [53]. Due to the importance or criticality of the products of the SCL, the customer even feels obliged (as a strategic choice) to accept the products of the SCL against a substantial price premium. In doing so, the customer's COGS rise, and his or her profitability sinks. Thus, we call this reasoning "profitability waiver thesis". If possible (products or materials of the SCL supplier are substitutable), the customer can reduce the dependency by the development of dual or even multiple sourcing.

Summing up, although the link between SCM and financial performance and the link between supply chain excellence and financial performance superiority has been studied in depth, only a few studies have analyzed suppliers or customers of SCL firms or the (financial) performance distribution through supply chains. No study has comprehensively explored the financial implications (spillovers) of being member of an SCL's network for suppliers and customers. This fact is astonishing, as the rationales behind supply chain relationships-a competitive viewpoint based on power regimes vs. cooperative viewpoints based on embeddedness-are for their part again well examined. Thus, the central purpose of this paper is to identify the potential implications for suppliers and customers who participate in an SCL's network.

\section{Methodology}

\subsection{Approach and Data Source}

We follow an explorative research approach with abductive reasoning [65]. Meaning, our reasoning starts with a deviating empirical observation, followed by an iterative reflection (discussion) with existing theory. According to the consistence ("degree of matching") between the empirical results and existing theory, new insights in the form of propositions are suggested. 
The present study is based on secondary financial data. The usage of secondary data is becoming increasingly common in logistics and supply chain research, as suggested by Rabinovich and Cheon [32] and Busse [33]. A key advantage of using secondary financial data is that the sample firms must not be kept anonymous. All of the examined companies of the study at hand are listed in Appendix A. The two databases used to export the data for this study were (i) the Bloomberg terminal and (ii) the Compustat database.

"Bloomberg is the popular subscription-based data service that provides a vast array of financial, economic and general information to users" [66] (p. 49). It provides all kinds of information on equities, bonds, etc. $[67,68]$. For the present study, the function "SPLC $\langle\mathrm{GO}\rangle$ " is important. This action provides information about the supply chains of companies and allows users to explore and deepen the topic of SCM. This function shows the key suppliers, customers and competitors of a focal firm and displays money flows between these firms.

In addition to Bloomberg, the Compustat database was used. This database covers approximately $98 \%$ of the world's total market capitalization, more than 65,000 firms globally, of which more than 45,500 are non-North American securities [69]. In similar studies, this database was used, among others, to find control firms for the statistical test and important information about companies $[4,15,70,71]$. For the present study, the Compustat database was used to export and select the control sample firms.

\subsection{Sample Selection}

The investigation is carried out from a simple supply chain perspective. We analyze the first-tier suppliers (upstream) and the first-tier customers (downstream) of long-term SCLs. Thus, the sample selection is based on real supplier-SCL or SCL-customer relationships. In order to diminish one-time effects, we looked for firms with complete data sets from a four-year time period (2011-2014). The overall sample selection process encompasses a five-step procedure (Figure 1).

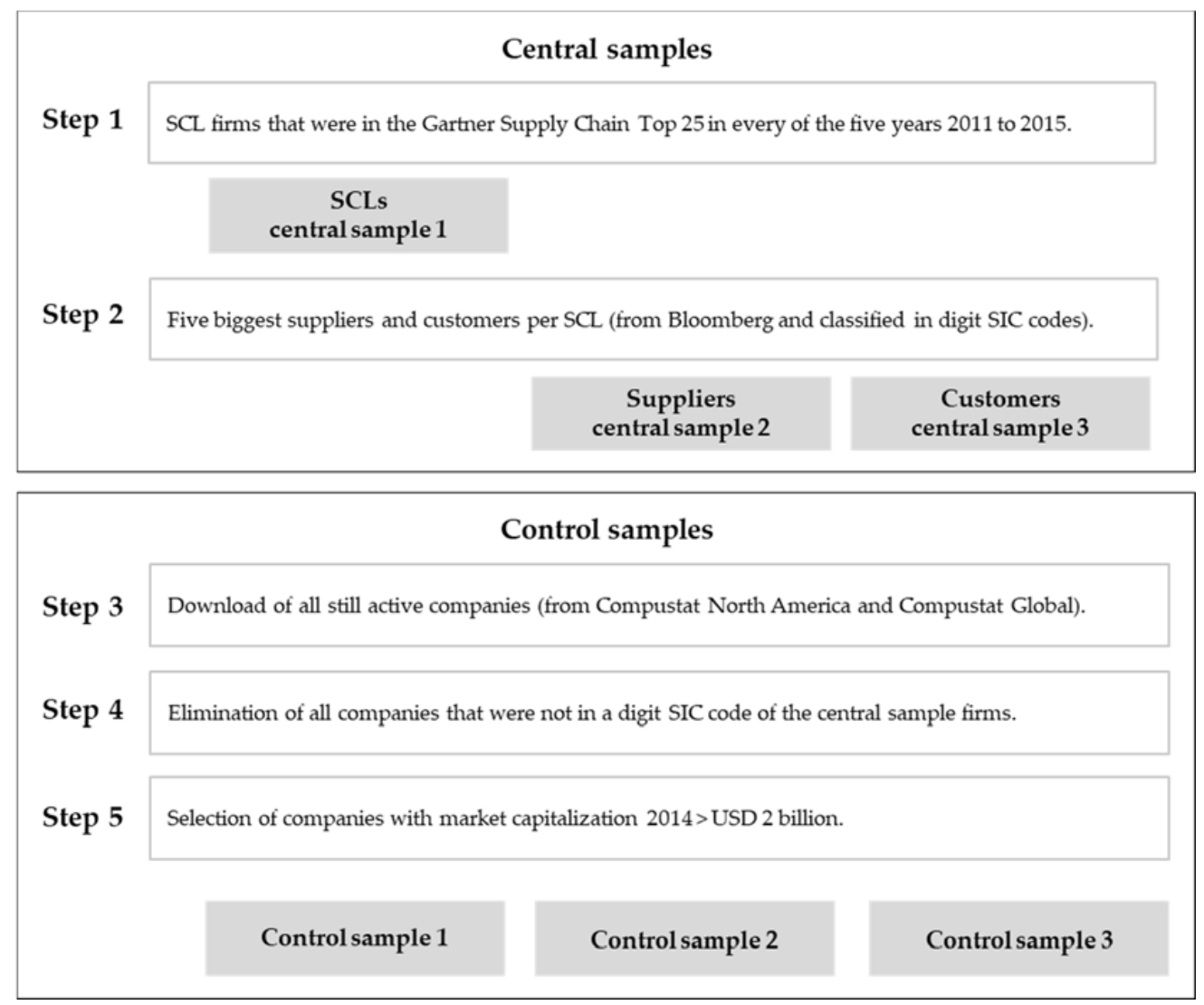

Figure 1. Procedure for selecting the samples. 
Step 1 encompasses the identification and selection of SCL firms (central sample 1). For this purpose, the Gartner Supply Chain Top 25 was used [72]. The Supply Chain Top 25 ranking was created from AMR Research in 2004. In 2010, AMR Research was acquired by the Gartner Group, which then took over the execution of this study [73]. The main goal behind the Gartner classification and analysis is "identifying global supply chain leaders and highlighting their best practices for heads of supply chain and strategy organizations" [74] (p. 15). Gartner [75] uses a composite score to determine its top 25 list. The composite score is divided into two components, a financial component and an opinion component, which are weighted $50 \%$ of the total score. The financial component comprises three financial metrics: return on assets $(\mathrm{ROA} ; 25 \%)=$ net income/total assets; inventory turns $(15 \%)=$ COGS/inventory; and revenue growth $(10 \%)=$ change in revenue from the prior year. The opinion component is composed of two different panels, which are equally weighted: Gartner analyst experts $(25 \%)$ and peer opinionists (25\%). Finally, all the information is normalized on a 10-point scale and combined with the weightings named above in a total composite score. To select "real" and long-term SCL firms, we decided to choose companies that were leaders for several years. For this reason, central sample 1 was restricted to companies that were listed as leaders in the Gartner Supply Chain Top 25 ranking (in every one of the years 2011 through 2015). The information about the companies was retrieved from Aronow et al. [76], Aronow et al. [74], Hofman [77], Hofman and Aronow [78] and Hofman et al. [79]. After eliminating one firm without a substantial group of control firms, data of 17 unique SCL firms (68 firm-years) was gathered.

In Step 2, the biggest suppliers (central sample 2) and the biggest customers (central sample 3) of each SCL were selected. The " $<$ SPLC $>$ GO" function in the Bloomberg terminal was used to detect the firms of the SCL networks. Looking upstream the supply chain, it is possible to break down four groups of suppliers, depending on the different types of costs of the SCL they supply to: COGS suppliers, SG\&A suppliers, CAPEX suppliers and R\&D suppliers. As these different suppliers tie different costs of focal firms (e.g., while from an accounting view COGS and SG\&A expenses are stated in the profit and loss statement, CAPEX and R\&D expenses have to be capitalized and are listed on the balance sheet), they must be analyzed separately. For a practical purpose, this study restricts the analysis to the five biggest COGS suppliers (measured as \% of COGS of SCLs) only, because the COGS is important for SCM, given that it "reflects the direct costs and overhead associated with the physical production of products for sale" [80] (p. 276). After adjustments (e.g. elimination of duplicates), the central sample 2 "biggest suppliers per each SCL" covered 56 unique firms, making-according the chosen four years period to elaborate long term relationships with the SCL (see above)-224 firm-years. Looking downstream the supply chain, the five biggest customers per SCL (measured as \% of revenue of SCLs) were selected. After adjustments, the central sample 3 "biggest customers per each SCL" included 42 unique firms and 168 firm-years. Table 1 summarizes the two steps and sub-steps for identifying and selecting the three central samples.

In Steps 3 to 5 , the control samples are selected. The present study compares SCLs, SCL-suppliers and SCL-customers with their peer groups in the same industry. This means that for every company in the central samples, all appropriate firms in the same industry (the same four-digit Standard Industrial Classification (SIC) code) were taken as the control sample [71]. To determine the benchmark of the industry, the median of the ratios was then calculated. Medians of at least three ratios (three available sets of company data) were used. To refine the control firms' selection and the benchmarking, the following procedure was applied. First, every firm still active in the Compustat database was downloaded with the four-digit SIC code (Step 3). Second, only the firms with an exact match based on the four-digit SIC codes of the central sample firms were considered (Step 4). Third, this sample was further restricted by including only firms that, in 2014, were at least mid-caps, meaning a market capitalization > USD 2 billion (Step 5). Appendix B shows the distribution of the three central samples' companies in market capitalization. This last step is relevant for selecting more robust control samples, considering that the central samples also contain bigger firms. Therefore, it makes sense to take large companies, which thus serve as stronger control firms, and the results can then be more significant. 
We consciously decided to apply the following design in order to have a larger database. On one hand, if we had decided on control sample firms with a market capitalization > USD 5 billion, we would have had to remove 7 of the 17 SCL companies from the analysis, due to missing of control sample data, thus drastically reducing the number of analyzed firms. On the other hand, we decided to use control sample firms > USD 2 billion as this is the entry level barrier for mid-cap companies. Figure 2 displays the number of firm-years $(\mathrm{N})$ in the samples and summarizes the sources or databases that were used to retrieve the information.

Table 1. Procedure for identifying the firms of the three central samples.

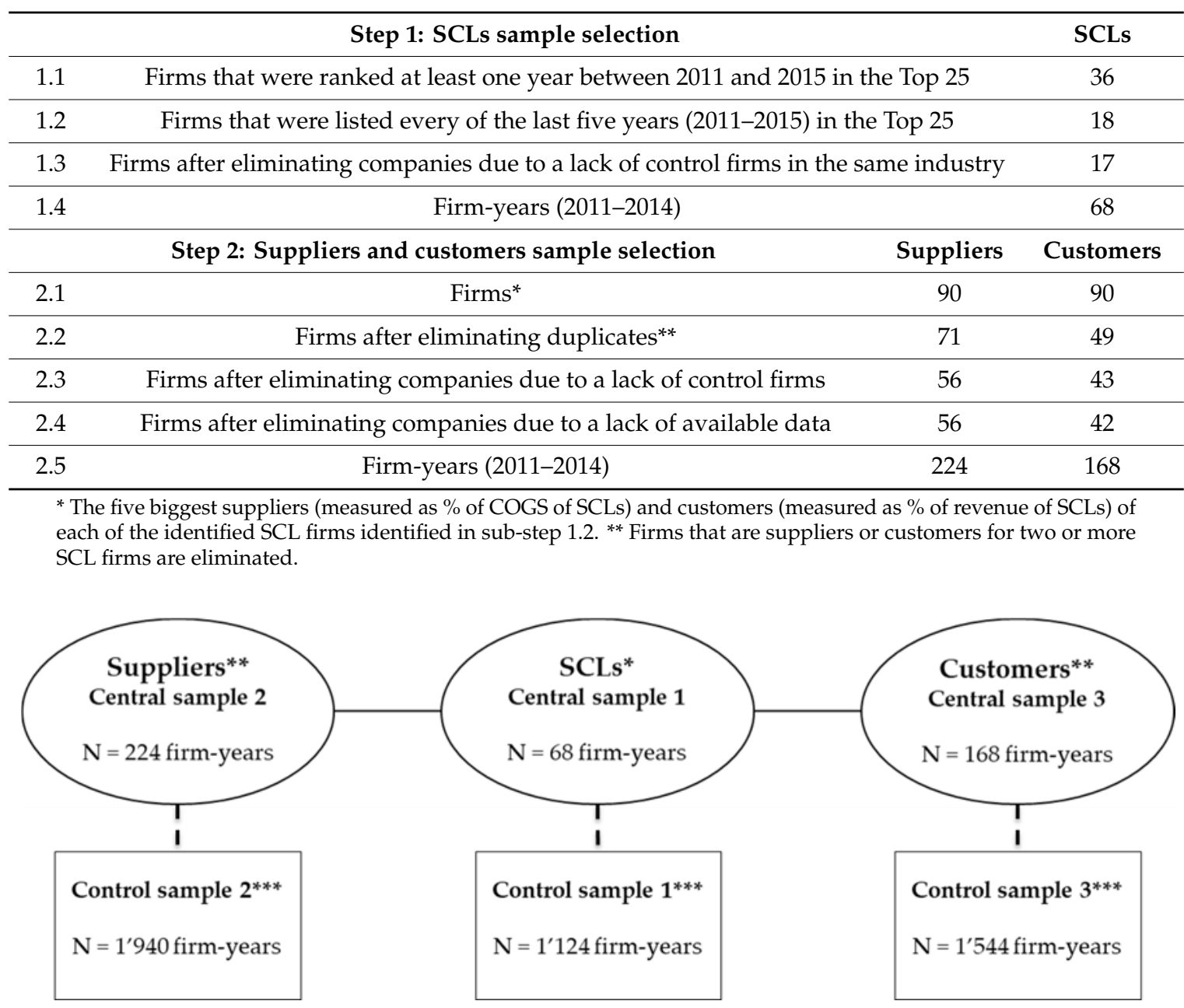

Figure 2. Number of firm-years in the samples and sources of data. * Sample selection source: Gartner Supply Chain Top 25. ${ }^{* *}$ Sample selection source: Bloomberg. ${ }^{* *}$ Sample selection source: Compustat. All company ratios are downloaded from Bloomberg. - Supply chain relationship. - - Wilcoxon signed rank test.

\subsection{Data Analysis}

The present study is based on Greer and Theuri's [15] work of analyzing the cost, liquidity and activity ratios of SCL firms. In order to take the study one step further, some ratios were added. The liquidity ratios are the operating cycle, CCC, current ratio and cash turnover. In contrast to Greer and Theuri's [15] study, the operating cycle was classified as the liquidity ratio, considering that it measures the time from acquisition of inventory and the realization of cash from sales. At the same time, the liquidity ratio is also very similar to the CCC, also named the net operating cycle, which is definitely classified as a liquidity ratio [46]. The CCC extends the operating cycle analysis by introducing accounts payable. Stewart [81] describes the CCC as "a composite metric describing the 
average days required to turn a dollar invested in raw material into a dollar collected from a customer" (p. 43). A positive CCC means that the focal company has increasing costs because of additional borrowed money [45]. If the CCC is short or even negative, the firm is receiving its accounts receivable from customers before paying its accounts payable to suppliers. In such a constellation, the company increases its liquidity and is financed by suppliers [44].

As activity ratios for this study, the following are selected: receivables turnover, asset turnover and days inventory outstanding (DIO). This is similar to the activity ratio analyzed by Greer and Theuri [15]. As mentioned, the operating cycle was displaced in the liquidity category.

Profitability is a new category, in comparison on Greer and Theuri's [15] work. For the purpose of this study, the two cost ratios were added to the profitability category, because of their direct impact on a firm's profit. The two additional profitability ratios, EBIT margin and return on capital employed (ROCE), look at the profit earned by the firm. While the EBIT margin concentrates on the income statement, the ROCE also incorporates the balance sheet and looks at the earning power of the total capital. Table 2 lists all the chosen ratios.

Table 2. Selected financial ratios.

\begin{tabular}{|c|c|c|c|}
\hline & Ratios & Formula & Bloomberg description* \\
\hline \multirow{4}{*}{ Liquidity } & Operating cycle** & $\begin{array}{c}\text { Accounts receivable turnover } \\
\text { in days }+ \text { inventory turnover } \\
\text { in days }\end{array}$ & $\begin{array}{l}\text { Measures the time between the acquisition of } \\
\text { inventory and the realization of cash from } \\
\text { sales of inventory. }\end{array}$ \\
\hline & $\begin{array}{l}\text { Cash conversion } \\
\text { cycle }\end{array}$ & $\begin{array}{c}\text { Accounts receivable turnover } \\
\text { in days + inventory turnover } \\
\text { in days - accounts payables } \\
\text { turnover in days }\end{array}$ & $\begin{array}{l}\text { Metric which expresses the length of time, in } \\
\text { days, that it takes for a company to convert } \\
\text { resource inputs into cash flows. }\end{array}$ \\
\hline & Current ratio & $\begin{array}{c}\text { Current assets/Current } \\
\text { liabilities }\end{array}$ & $\begin{array}{l}\text { Ratio to indicate the company's ability to pay } \\
\text { back its short-term liabilities with its } \\
\text { short-term assets. }\end{array}$ \\
\hline & Cash turnover & Sales/Cash & $\begin{array}{l}\text { Cash and near cash turnover ratio measures } \\
\text { how effective a company is utilizing its cash. }\end{array}$ \\
\hline \multirow[t]{3}{*}{ Activity } & $\begin{array}{l}\text { Receivable } \\
\text { turnover }\end{array}$ & Sales/Average total receivables & $\begin{array}{l}\text { Ratio that measures how many times a } \\
\text { business can collect its average accounts } \\
\text { receivable during the year. }\end{array}$ \\
\hline & Assets turnover & Sales/Average total assets & $\begin{array}{l}\text { The ratio is an indicator of the efficiency with } \\
\text { which a company is deploying its assets. }\end{array}$ \\
\hline & $\begin{array}{l}\text { Days inventory } \\
\text { outstanding }\end{array}$ & (Inventory/COGS) $\times 360$ & $\begin{array}{l}\text { Average number of days that goods remain in } \\
\text { inventory before being sold. }\end{array}$ \\
\hline \multirow{4}{*}{ Profitability } & EBIT margin & $($ EBIT/Sales $) \times 100$ & $\begin{array}{c}\text { Earnings before interest and taxes (EBIT) as a } \\
\text { percentage of net sales. }\end{array}$ \\
\hline & $\begin{array}{l}\text { Return on capital } \\
\text { employed }\end{array}$ & (EBIT/Capital employed $) \times 100$ & $\begin{array}{l}\text { Ratio which indicates the company's ability } \\
\text { to use its capital investment efficiently. }\end{array}$ \\
\hline & COGS to sales & $($ COGS/Sales $) \times 100$ & $\begin{array}{l}\text { Percentage of revenue (net sales) used to pay } \\
\text { costs of goods sold. }\end{array}$ \\
\hline & SG\&A to sales & $($ SG\&A/Sales $) \times 100$ & $\begin{array}{l}\text { Selling, general, and administrative (SG\&A) } \\
\text { expenses as a percentage of total sales. }\end{array}$ \\
\hline
\end{tabular}

${ }^{*}$ Considering that the data for the analysis are downloaded from the Bloomberg database, if not otherwise specified, the ratio definitions are retrieved from the find fields in the Bloomberg tab. The names and formulas of the ratios were simplified and unified to promote understanding. **Bloomberg does not have a direct formula for the operating cycle, so it must be calculated with the two indicated components.

The data was gathered from 2011 until 2014 for each company from the Bloomberg database. The ratios of the firms in the control samples were used to calculate the industry benchmark. The median of all ratios of the same year of each firm in the same four-digit SIC code was calculated. In this study, the median is preferred to the arithmetic mean because "medians are considered to be better indicators. As accounting data are not normally distributed, the medians are extremely robust to outliers and other deviations from normality" [70] (pp. 181-182). 
In order to identify significant differences between the ratios of suppliers and customers of SCLs and the ratios of control firms in the same industry, we used the Wilcoxon signed rank test (for a theoretical deepening of the approach, see Weiers [82] (pp. 505-517); for additional examples of the application of the approach in literature, see Greer and Theuri [15], Santhanam and Hartono [71], Bharadwaj [70] and Kalwani and Narayandas [4]). This approach is a nonparametric test, which can be used for comparing paired samples. As the name reveals, the test compares a sample with another (paired) sample [82] (p. 513). According to Weiers [82], "[a] nonparametric test is one that makes no assumptions about the specific shape of the population from which the sample is drawn" (p. 506). Thus, the Wilcoxon signed rank test is the nonparametric counterpart of the paired-samples t-test and compares two dependent samples. Compared to the paired t-test, the Wilcoxon signed rank test is seen as more robust against outliers [83]. Another advantage is the small sizes samples can have.

The logic and procedure for detecting the test statistic $W$ is listed (the procedure is from Weiers [82] (pp. 508-517)):

1. Create a column with the $x_{i}$ and $y_{i}$ samples and structure them in a way that the paired samples are on the same line.

2. Calculate the difference between the paired observations, $d_{i}=x_{i}-y_{i}$. This is also the measurement of interest for the purpose of the test.

3. Calculate the absolute value of $d_{i}=\mathrm{I} d_{i} \mathrm{I}$, by ignoring $d_{i}=0$ values and calculating for tied rows the average of their position. The $\mathrm{I} d_{i} \mathrm{I}$ has to be ranked in descending order, so that the smallest $\mathrm{I} d_{i} \mathrm{I}$ has rank 1 .

4. List the rank of observations where $x_{i}>y_{i}$ in the $R+$ column.

5. Finally, calculate the test statistic by summing these positive differences $\left(W=\sum R+\right)$.

If the number of the nonzero differences $\left(d_{i} \neq 0\right)$ exceeds $20(\mathrm{n} \geq 20)$, it is possible to use a normal approximation of the Wilcoxon signed rank test. For the purpose of the study, this assumption is satisfactory. For the normal approximation, we need the $z$-formula, which looks like the following [82] (p. 510):

$$
z=\frac{W-\frac{n(n+1)}{4}}{\sqrt{\frac{n(n+1)(2 n+1)}{24}}},
$$

where $W$ is the sum of the $\mathrm{R}+$ ranks, and $n$ is the number of observations for which $\mathrm{d}_{\mathrm{i}} \neq 0$.

\section{Results}

\subsection{Relationship Distribution}

Before the results are described, the relationship between the supply chain members and the central samples' distribution in industries is briefly shown. This provides the basis for the discussion and helps to interpret the findings. The relationship between suppliers and SCLs and SCLs and customers is displayed in Figure 3. It shows the companies' percentage of revenue or COGS they impact. For the data information, the mean, median and standard deviation (SD) of the analyzed companies are provided. Generally, it appears that SCLs have a lower percentage (in the mean and the median) in costs and revenues than the suppliers and customers. This shows that SCLs are less dependent on their relationship with suppliers and customers than vice versa. Looking at the suppliers and customers, it becomes clear that suppliers (SCLs \% of revenues) are the most dependent companies. They exceed the customers (SCLs \% of COGS) by 1.82 percentage points in the mean and by 1.09 percentage points in the median.

Table 3 classifies the central samples in the SIC divisions, in order to get an initial impression of the position of the sample companies in the supply chains. Although most of the SCLs (70.6\%) and suppliers $(85.7 \%)$ are active in the manufacturing division, $40.5 \%$ of the customer firms work in the retail trade business. Many customer companies are also active in manufacturing (38.1\%). See more information about the classification of the samples in SIC code in Appendix A and about the samples descriptive data in Appendix B. 


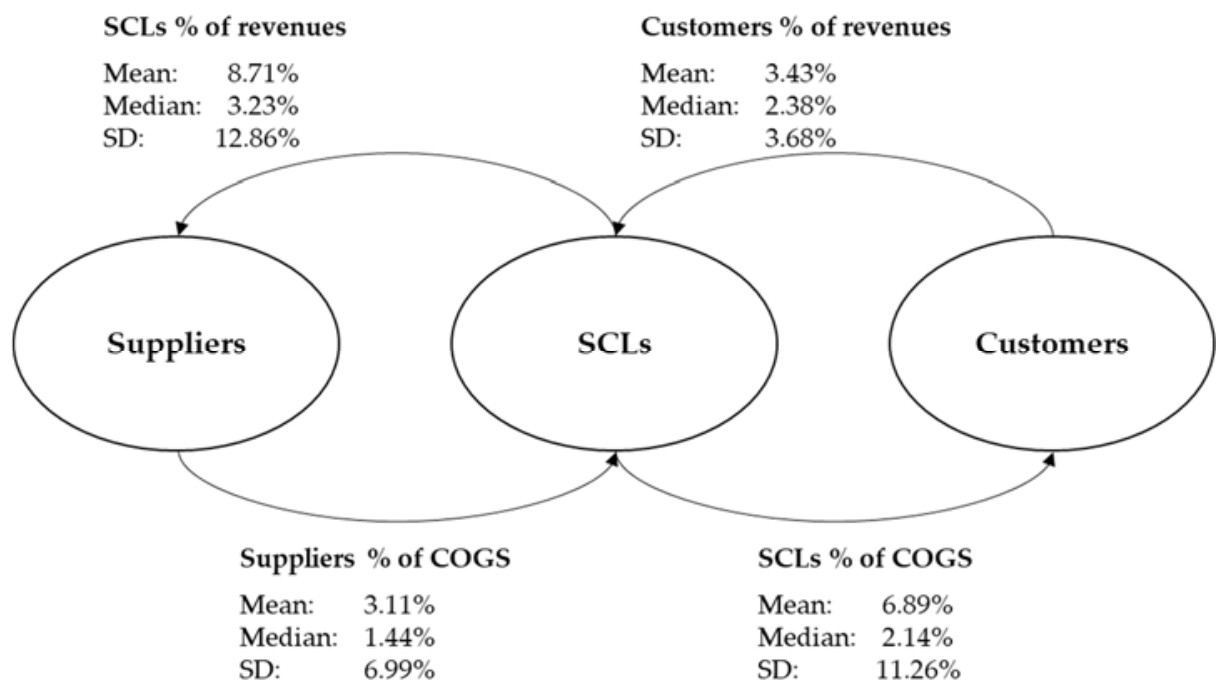

Figure 3. Relationship strength within the SCL networks.

Table 3. Distribution of central sample firms in SIC divisions.

\begin{tabular}{ccccccc}
\hline \multirow{2}{*}{ SIC division } & \multicolumn{2}{c}{ SCLs } & \multicolumn{2}{c}{ Suppliers } & \multicolumn{2}{c}{ Customers } \\
\cline { 2 - 7 } & $\mathbf{N}$ & $\%$ & $\mathbf{N}$ & $\%$ & $\mathbf{N}$ & $\%$ \\
\hline Manufacturing & 12 & $70.6 \%$ & 48 & $85.7 \%$ & 16 & $38.1 \%$ \\
\hline Transportation \& Public Utilities & - & - & 3 & $5.4 \%$ & 6 & $14.3 \%$ \\
\hline Wholesale Trade & 1 & $5.9 \%$ & 3 & $5.4 \%$ & 3 & $7.1 \%$ \\
\hline Retail Trade & 4 & $23.5 \%$ & - & - & 17 & $40.5 \%$ \\
\hline Finance, Insurance, Real Estate & - & - & 1 & $1.8 \%$ & - & - \\
\hline Services & - & - & 1 & $1.8 \%$ & - & - \\
\hline
\end{tabular}

The descriptive results illustrate that whereas SCLs and suppliers are one step before the consumption point, most of the customers have direct contact with end consumers.

\subsection{Supply Chain Leaders (SCLs)}

In line with Greer and Theuri [15], we conducted an analysis to confirm their results, that SCL firms have significantly better financial ratios than control firms in the same industries. Table 4 presents the results for SCLs. Although $76.5 \%$ of the analyzed companies are from the US, all firms are at least large caps $(70.6 \%)$ or even bigger, mega-caps $(29.4 \%)$. Far more than half of the companies $(70.6 \%)$ have more than 100,000 employees.

In the following, each ratio result is briefly described (mainly the medians).

Liquidity Ratios. The operating cycle (91.383 for SCLs vs. 112.072 for control firms) and the CCC (34.483 for SCLs vs. 46.534 for control firms) of SCL firms are statistically significantly lower (at the $1 \%$ level). The current ratio (1.351 for SCLs vs. 1.512 for control firms) is also shown to be statistically significantly lower (at the $1 \%$ level). A general rule for the current ratio is that it should total $200 \%$ (this means looking at the results 2 ) and be at least $100 \%$. In this case, the control firms seem to have safer current ratios, which contradicts Greer and Theuri's [15] (pp. 102-103) findings. Even if the control firms seem to have a better ratio, the SCLs' current ratio nevertheless exceeds the minimum limit of 1. The cash turnover (11.130 for SCLs vs. 8.260 for control firms) of SCLs, however, is statistically significantly higher (at the 1\% level) compared with that of the control firms. The lower operating cycles and CCCs together with the higher cash turnover ratios imply that SCL firms are associated with significantly better liquidity ratios than control firms in the same industries. 
Table 4. Comparison of ratios for SCLs and control firms.

\begin{tabular}{|c|c|c|c|c|c|c|}
\hline & Ratios & Sample & $\mathbf{N}$ & Mean & Median & $\mathbf{Z}$ \\
\hline \multirow{8}{*}{ Liquidity } & \multirow{2}{*}{ Operating cycle } & SCLs & 68 & 89.569 & 91.383 & \multirow{2}{*}{$5.505^{* * *}$} \\
\hline & & Control & 1043 & 120.905 & 112.072 & \\
\hline & \multirow{2}{*}{ Cash conversion cycle } & SCLs & 64 & 29.062 & 34.483 & \multirow{2}{*}{$4.641^{* * *}$} \\
\hline & & Control & 940 & 62.584 & 46.534 & \\
\hline & \multirow{2}{*}{ Current ratio } & SCLs & 68 & 1.612 & 1.351 & \multirow{2}{*}{$2.542^{* * *}$} \\
\hline & & Control & 1114 & 1.822 & 1.512 & \\
\hline & \multirow{2}{*}{ Cash turnover } & SCLs & 68 & 14.265 & 11.130 & \multirow{2}{*}{$-3.391^{* * *}$} \\
\hline & & Control & 1111 & 10.632 & 8.260 & \\
\hline \multirow{6}{*}{ Activity } & \multirow{2}{*}{ Receivable turnover } & SCLs & 68 & 18.724 & 10.692 & \multirow{2}{*}{$-3.660^{* * * *}$} \\
\hline & & Control & 1081 & 13.213 & 9.105 & \\
\hline & \multirow{2}{*}{ Asset turnover } & SCLs & 68 & 1.059 & 0.914 & \multirow{2}{*}{0.984} \\
\hline & & Control & 1104 & 1.109 & 1.023 & \\
\hline & \multirow{2}{*}{$\begin{array}{l}\text { Days inventory } \\
\text { outstanding }\end{array}$} & SCLs & 68 & 59.316 & 60.541 & \multirow{2}{*}{$4.729^{* * *}$} \\
\hline & & Control & 1057 & 75.608 & 63.505 & \\
\hline \multirow{8}{*}{ Profitability } & \multirow{2}{*}{ EBIT margin } & SCLs & 68 & 18.408 & 18.335 & \multirow{2}{*}{$-6.251^{* * *}$} \\
\hline & & Control & 1115 & 10.229 & 10.149 & \\
\hline & \multirow{2}{*}{$\begin{array}{l}\text { Return on capital } \\
\text { employed }\end{array}$} & SCLs & 67 & 42.761 & 32.306 & \multirow{2}{*}{$-5.703^{* * *}$} \\
\hline & & Control & 855 & 21.153 & 20.234 & \\
\hline & \multirow{2}{*}{ COGS to sales } & SCLs & 68 & 51.812 & 51.924 & \multirow{2}{*}{$3.837^{* * *}$} \\
\hline & & Control & 1077 & 59.331 & 55.584 & \\
\hline & \multirow{2}{*}{ SG\&A to sales } & SCLs & 60 & 23.598 & 25.307 & \multirow{2}{*}{-1.229} \\
\hline & & Control & 882 & 22.649 & 20.320 & \\
\hline
\end{tabular}

Significance: * $10 \%$ level, ${ }^{* *} 5 \%$ level, ${ }^{* * *} 1 \%$ level.

Activity Ratios. The statistically significantly higher (at the 1\% level) receivables turnover (10.692 for SCLs vs. 9.105 for control firms), together with the statistically significantly lower (at the 1\% level) DIO (60.541 for SCLs vs. 63.505 for control firms) show that SCL firms have better activity ratios compared to firms in the same industries.

Profitability Ratios. The EBIT margin (18.335 for SCLs vs. 10.149 for control firms) and the ROCE (32.306 for SCLs vs. 20.234 for control firms) of SCL firms are statistically significantly higher (at the 1\% level) than their respective industry benchmarks. The COGS to sales ratios (51.924 for SCLs vs. 55.584 for control firms) are shown to be statistically significantly lower (at the 1\% level) than that of peers in the same industry. The SG\&A to sales ratios are higher (25.307 for SCLs vs. 20.320 for control firms) for SCLs, but the results do not reach statistical significance. This seems to be in line with the results obtained by Bharadwaj [70] (p. 182) for IT leaders. In sum, the higher EBIT margin and ROCE and lower COGS to sales show that SCL firms are associated with better profitability ratios.

In summary, SCLs are associated with significantly superior liquidity, activity and profitability ratios. These results are in harmony with that of Greer and Theuri [15]. The following analysis extends their study by analyzing the suppliers and customers of SCL firms.

\subsection{Suppliers}

The suppliers of SCLs are, similar to the SCLs for their part, mostly US companies (51.8\%). Around one fifth $(21.4 \%)$ of the firms in this sample are from Asian countries: Japan (8.9\%), South Korea (7.1\%) and Taiwan (5.4\%). The majority of the suppliers are large caps (42.9\%) and mid-caps (39.3\%). Most $(67.8 \%)$ have more than 10,000 employees, $21.4 \%$ of which have more than 100,000 workers. Compared 
to the SCLs sample, the suppliers' sample contains smaller companies: $85.7 \%$ of these firms are active in the manufacturing SIC division. The results for the suppliers of SCL firms are displayed in Table 5.

Table 5. Comparison of ratios for suppliers of SCLs and control firms.

\begin{tabular}{|c|c|c|c|c|c|c|}
\hline & Ratios & Sample & $\mathbf{N}$ & Mean & Median & $\mathbf{Z}$ \\
\hline \multirow{8}{*}{ Liquidity } & \multirow{2}{*}{ Operating cycle } & Suppliers & 198 & 104.820 & 96.995 & \multirow{2}{*}{$3.840^{* * *}$} \\
\hline & & Control & 1407 & 116.172 & 113.558 & \\
\hline & \multirow{2}{*}{ Cash conversion cycle } & Suppliers & 191 & 53.799 & 44.473 & \multirow{2}{*}{$4.258^{* * *}$} \\
\hline & & Control & 1279 & 64.128 & 59.893 & \\
\hline & \multirow{2}{*}{ Current ratio } & Suppliers & 216 & 1.833 & 1.495 & \multirow{2}{*}{$3.008^{* * *}$} \\
\hline & & Control & 1710 & 1.823 & 1.732 & \\
\hline & \multirow{2}{*}{ Cash turnover } & Suppliers & 220 & 18.724 & 11.164 & \multirow{2}{*}{$-4.416^{* * *}$} \\
\hline & & Control & 1915 & 13.114 & 8.150 & \\
\hline \multirow{6}{*}{ Activity } & \multirow{2}{*}{ Receivable turnover } & Suppliers & 213 & 9.368 & 8.420 & \multirow{2}{*}{$-3.874^{* * *}$} \\
\hline & & Control & 1671 & 7.717 & 7.477 & \\
\hline & \multirow{2}{*}{ Asset turnover } & Suppliers & 217 & 1.173 & 0.941 & \multirow{2}{*}{$-3.558^{* * *}$} \\
\hline & & Control & 1907 & 0.986 & 0.771 & \\
\hline & \multirow{2}{*}{$\begin{array}{l}\text { Days inventory } \\
\text { outstanding }\end{array}$} & Suppliers & 199 & 58.354 & 51.290 & \multirow{2}{*}{$4.021^{* * *}$} \\
\hline & & Control & 1419 & 66.442 & 63.836 & \\
\hline \multirow{8}{*}{ Profitability } & \multirow{2}{*}{ EBIT margin } & Suppliers & 217 & 6.498 & 6.582 & \multirow{2}{*}{$5.023^{* * *}$} \\
\hline & & Control & 1712 & 11.153 & 10.697 & \\
\hline & \multirow{2}{*}{$\begin{array}{l}\text { Return on capital } \\
\text { employed }\end{array}$} & Suppliers & 167 & 37.903 & 15.784 & \multirow{2}{*}{-0.686} \\
\hline & & Control & 982 & 19.029 & 17.775 & \\
\hline & \multirow{2}{*}{ COGS to sales } & Suppliers & 207 & 73.544 & 78.890 & \multirow{2}{*}{$-3.958^{* * *}$} \\
\hline & & Control & 1584 & 68.457 & 66.895 & \\
\hline & \multirow{2}{*}{ SG\&A to sales } & Suppliers & 156 & 14.815 & 10.129 & \multirow{2}{*}{0.177} \\
\hline & & Control & 1233 & 14.334 & 11.887 & \\
\hline
\end{tabular}

Significance: * $10 \%$ level, ${ }^{* *} 5 \%$ level, ${ }^{* * *} 1 \%$ level.

Liquidity Ratios. The operating cycle (96.995 for suppliers vs. 113.558 for control firms) and the CCC (44.473 for suppliers vs. 59.893 for control firms) of the SCL suppliers are statistically significantly lower (at the 1\% level) compared to that of control firms in the same industry. The current ratio (1.495 for suppliers vs. 1.732 for control firms) is also statistically significantly lower (at the 1\% level). Similar to the SCLs' current ratio, in this case, the control firms' current ratio is closer to 2. Consequently, the same as for the SCLs is true here. The cash turnover (11.164 for suppliers vs. 8.150 for control firms) of suppliers, however, is statistically significantly higher (at the 1\% level) compared with that of the control firms. The lower operating cycle and the CCC together with the higher cash turnover ratios imply that SCL suppliers are associated with significantly better liquidity ratios than control firms in the same industries.

Activity Ratios. The Wilcoxon signed rank test indicates that the receivables turnover (8.420 for SCL suppliers vs. 7.477 for control firms) and the asset turnover (0.941 for suppliers vs. 0.771 for control firms) are statistically significantly higher (at the 1\% level) than those of the control firms in the same industries. In contrast, the DIO (51.290 for suppliers vs. 63.836 for control firms) are statistically significantly lower (at the 1\% level). This result shows that SCL supplier firms also possess significantly better activity ratios. 
Profitability Ratios. There is evidence (at the 1\% level) that SCL suppliers' EBIT margins (6.582 for SCL suppliers vs. 10.697 for control firms) are statistically significantly lower than the industry benchmarks. The COGS to sales (78.890 for suppliers vs. 66.895 for control firms) ratios are statistically significantly higher (at the 1\% level) than that of the control firms in the same industry. As the ROCE and the SG\&A to sales ratios do not present statistically significant results, SCL suppliers possess smaller profitability ratios.

In summary, suppliers of SCLs are associated with significantly superior liquidity and activity but inferior profitability ratios.

\subsection{Customers}

The majority of the SCL customer firms are US companies (47.6\%). A smaller portion of companies $(26.1 \%)$ are from Japan (9.5\%), Great Britain (9.5\%) and France $(7.1 \%)$. The majority of the firms are at least large caps $(76.1 \%)$, of which $7.1 \%$ are mega-caps. Most of the customers $(61.9 \%)$ have more than 100,000 employees. This shows that this sample, compared to the SCL suppliers' sample, is made up of bigger companies. The majority $(40.5 \%)$ of these firms are active in the retail trade SIC division: $38.1 \%$ of the firms are in the manufacturing sector and $14.3 \%$ in the transportation and public utilities SIC division. The results for the customers of SCL firms are displayed in Table 6.

Table 6. Comparison of ratios for customers of SCLs and control firms.

\begin{tabular}{|c|c|c|c|c|c|c|}
\hline & Ratios & Sample & $\mathbf{N}$ & Mean & Median & $\mathrm{Z}$ \\
\hline \multirow{8}{*}{ Liquidity } & \multirow{2}{*}{ Operating cycle } & Customers & 149 & 79.549 & 66.288 & \multirow{2}{*}{$2.954^{* * *}$} \\
\hline & & Control & 1295 & 88.494 & 88.494 & \\
\hline & \multirow{2}{*}{ Cash conversion cycle } & Customers & 147 & 29.408 & 25.360 & \multirow{2}{*}{-1.187} \\
\hline & & Control & 1262 & 27.096 & 27.062 & \\
\hline & \multirow{2}{*}{ Current ratio } & Customers & 168 & 1.277 & 1.091 & \multirow{2}{*}{1.210} \\
\hline & & Control & 1521 & 1.263 & 1.210 & \\
\hline & \multirow{2}{*}{ Cash turnover } & Customers & 167 & 35.554 & 14.830 & \multirow{2}{*}{$-4.068^{* * *}$} \\
\hline & & Control & 1514 & 16.106 & 11.538 & \\
\hline \multirow{6}{*}{ Activity } & \multirow{2}{*}{ Receivable turnover } & Customers & 159 & 26.753 & 11.567 & \multirow{2}{*}{$-2.411^{* * *}$} \\
\hline & & Control & 1455 & 23.090 & 9.487 & \\
\hline & \multirow{2}{*}{ Asset turnover } & Customers & 167 & 1.433 & 1.189 & \multirow{2}{*}{0.859} \\
\hline & & Control & 1478 & 1.329 & 1.392 & \\
\hline & \multirow{2}{*}{$\begin{array}{l}\text { Days inventory } \\
\text { outstanding }\end{array}$} & Customers & 158 & 47.368 & 38.229 & \multirow{2}{*}{$2.931^{* * *}$} \\
\hline & & Control & 1336 & 51.908 & 48.956 & \\
\hline \multirow{8}{*}{ Profitability } & \multirow{2}{*}{ EBIT margin } & Customers & 168 & 7.597 & 5.934 & \multirow{2}{*}{$2.176^{* *}$} \\
\hline & & Control & 1516 & 8.007 & 5.574 & \\
\hline & \multirow{2}{*}{$\begin{array}{l}\text { Return on capital } \\
\text { employed }\end{array}$} & Customers & 145 & 28.598 & 18.441 & \multirow{2}{*}{-0.342} \\
\hline & & Control & 1040 & 20.267 & 20.118 & \\
\hline & \multirow{2}{*}{ COGS to sales } & Customers & 164 & 70.504 & 73.134 & \multirow{2}{*}{$-2.102^{* *}$} \\
\hline & & Control & 1378 & 68.925 & 74.717 & \\
\hline & \multirow{2}{*}{ SG\&A to sales } & Customers & 138 & 18.020 & 19.010 & \multirow{2}{*}{0.231} \\
\hline & & Control & 1107 & 17.751 & 14.643 & \\
\hline
\end{tabular}

Significance: ${ }^{*} 10 \%$ level, ${ }^{* *} 5 \%$ level, ${ }^{* * *} 1 \%$ level. 
Liquidity Ratios. The operating cycle of SCL customers (66.288 for SCL customers vs. 88.494 for control firms) is statistically significantly lower (at the $1 \%$ level) compared to that of control firms in the same industry. In addition, the CCC as the current ratio presents misleading results if the mean and the median are compared. Further, neither ratio has statistically significant results. The cash turnover (14.830 for customers vs. 11.538 for control firms) of customers is statistically significantly higher (at the 1\% level) compared to that of control firms in the same industry. The lower operating cycles, together with the higher cash turnover, imply that SCL customer firms are associated with significantly better liquidity ratios than control firms in the same industry.

Activity Ratios. Although the receivables turnover for SCL customers (11.567 for SCL customers vs. 9.487 for control firms) is statistically significantly higher (at the $1 \%$ level), the DIO (38.229 for SCL customers vs. 48.956 for control firms) are statistically significantly lower (at the $1 \%$ level) than that of control firms in the same industry. These results show that SCL customer firms are associated with significantly better activity ratios.

Profitability Ratios. The test statistic shows that SCL customers' EBIT margins are statistically significantly lower (at the $5 \%$ level) than the industry benchmarks. In addition, although the SCL customers' mean is smaller than that of the control samples', the median is higher. This says something about the distribution of the data. This effect could be because the average distance of the firms' ratios above the median is smaller, and/or the average distance of the customers' ratios below the median is larger. Further, the COGS to sales ratio is statistically significantly higher (at the $5 \%$ level) than that of control firms in the same industry. For the COGS to sales ratio, the same phenomenon as for the EBIT margin appears, only inverted. Although the ROCE as the SG\&A to sales ratio does not present significant results, SCL customers have smaller profitability ratios than their peers.

Summing up, customers of SCL firms are associated with significantly superior liquidity and activity but inferior profitability ratios.

\section{Discussion}

\subsection{SCL Networks as a Source of Liquidity}

By analyzing supplier-buyer relationships, Patatoukas [25] showed that suppliers, among others, can reduce their CCC through relationships with major customers. Lanier et al. [24], by investigating a concentrated three-firm SC, demonstrated that positive CCC results are distributed across the supply chain, with some indication that upstream members benefit more. Furthermore, Gosman and Kohlbeck [21] showed that suppliers of powerful retailers are associated with a lower CCC. These results are, to some extent, in line with our results in which suppliers and SCLs have statistically significantly superior liquidity ratios. Although SCL suppliers display a 15.4 day shorter CCC against peers, SCL firms for their part show a 12.1 day shorter CCC compared to their control samples. By deepening the results, it becomes clear that SCL suppliers have superior operating cycles and CCCs, while SCL customers are associated only with superior operating cycles. The customers' CCC seems to be inferior, but with no significance. These results could be explained by a few factors. On one hand, in line with Gosman and Kohlbeck [21], as well as Gosman and Kelly [62], the suppliers seem to balance some of the negative effects, by transferring some of the negative performance effects to their suppliers (upstream the supply chain). In addition, looking at the suppliers-SCLs' relationship, it seems, in line with Hofmann and Kotzab [84], as if there is an improvement of the CCC in the supply chain through an optimization at the external supply chain boundaries. However, customers seem to be unable to offset the pressure of SCLs through their respective customers and are forced to pay SCLs more quickly, which reduces their accounts payable. Nevertheless, it must be pointed out that for the customers the CCC was not found to be significantly inferior. Thus, even if it seems that customers are under pressure by SCL firms, customers still possess superior liquidity ratios. 
As the present results significantly show, suppliers and customers of SCL firms are associated with superior liquidity ratios, which suggests that these firms can better meet short-term obligations. Thus, our first proposition is as follows:

Proposition 1. Within an SCL's network, cash is provided for suppliers and customers associated with superior liquidity ratios for the affiliated supply chain partners.

This proposition is in line with the "(liquidity) redistribution thesis" as suggested by Meltzer [85], Petersen and Rajan [86] and Cuñat [87], who posit that firms with better access to capital redistribute the cash to less advantaged firms. This means, in general, suppliers are paid faster by SCLs [88], and customers are granted longer payment terms [89]. In a figurative sense, the supply chain with a financially strong SCL firm serves as a source of liquidity for the affiliated up- and downstream members - an insight which should be paid much more attention in future supply chain investigations.

\subsection{SCL Networks as an Accelerator for Activities}

Looking at the activity ratios of suppliers and customers, the results are analogous to liquidity ratios and show superior results compared to industry peers. As previously seen, the ratio categories are not mutually exclusive, meaning, for example, that sometimes activity ratios could also be useful for calculating the liquidity of a firm [46]. Therefore, the previous and following sections should not be strictly separated.

Looking at the supplier side, the activity ratio results are in line with Patatoukas [25], who found that suppliers reported lower assets in inventory and higher asset turnover. Lanier et al. [24] suggest that asset utilization is shared between the members, noting that this resource distribution is central to the competitive advantage of the supply chain. Previous articles and studies have shown that buyer power, created by retailer consolidation, enables the dominant party, among others, to carry less inventory and extend payables to suppliers $[21,22,62,90]$. In contrast to these studies, the present results showed that suppliers and customers have superior activity ratios. Although suppliers are associated with higher receivables turnover (0.9 higher than the control firms), higher asset turnover (0.2 higher than the control firms) and 12.5 day shorter DIO against peers, customers show a 2.1 higher receivables turnover and 10.7 day shorter DIO.

The present results can be explained by the "knowledge transfer thesis" [21,62] and the joint learning approach, meaning that successful firms (like SCLs) establish their practice excellence by suppliers and customers. This is in line with the well-studied relevance of long-term relationships in supply chains [91,92]. Ford Motor Company is an example, showing that a change from an adversarial to a cooperative relationship with suppliers can improve competitiveness [93]. Extending that idea, Carr and Pearson [60] found empirical evidence that a cooperative relationship between suppliers and buyers increases both companies' performance.

As suppliers and customers of SCL firms are associated with superior activity ratios, these firms are able to manage their resources more efficiently. We suggest a second proposition:

Proposition 2. Within an SCL's network, suppliers and customers will benefit from know-how exchange associated with superior activity ratios for the affiliated supply chain partners.

\subsection{Profitability Exploitation across SCL Networks}

In addition, by looking at the suppliers' and customers' profitability, the results are unambiguous. Both are associated with statistically significantly inferior ratios compared to those for the control firms in the same industry.

Referring to our analysis, suppliers showed clearer tendency (at the $1 \%$ level of significance) than customers (at the 5\% level of significance). Although suppliers exhibited a $4.1 \%$ lower EBIT margin, 
their COGS to sales ratio was $12.0 \%$ higher, which demonstrates their profitability ratios' inferiority compared to their peers. The customers' EBIT margin and COGS to sales ratio results compared to the control samples show different and confounding means and medians. This result says something about the data distribution and not the statistical results. The difference between the customer ratios and those of the control peers is smaller than that of suppliers.

In a supplier-SCL or SCL-customer relationship, the powerful actors are per definition the SCL firms, as they are commonly bigger companies, which are less dependent on their supply chain partners (see Appendix B). Following our results, it could be suggested that SCLs exploit their power by profitability ratios. Duffy and Fearne [63] showed that power asymmetry is negatively associated with sharing of benefits between partners. Especially on the supply side, studies have shown that buyer power is negatively associated with suppliers' profitability. For instance, Gosman and Kohlbeck [21] found that suppliers' gross margin and ROA are negatively correlated with an improvement in sales to major customers. A reason could be the influence of dominant actors over suppliers that are forced, for example, through open-book accounting practices to provide information about cost and profit to their powerful partners, which can use this information to enforce price reductions [62]. This is in line with Bianco and Zellner [90] who pointed out that, for example, a firm like Wal-Mart strongly influences prices by cost reductions of products among its upstream business partners.

Based on these argumentations, we conclude with the third proposition:

Proposition 3. Within an SCL's network, concessions must be made by suppliers and customers associated with inferior profitability ratios for the affiliated supply chain partners.

In addition, the "profitability waiver thesis" seems to be an alternative reason for this third proposition. Based on the strategic choice approach, a profitability waiver can be interpreted as a sort of "interest rate" to pay, with the SCL as a customer (from the perspective of the suppliers) and with the SCL as an important brand supplier (from the perspective of the customers). This is not to say that such relationships to SCLs are less attractive; instead, the profitability waiver seems to be a conscious compensation of being part of the SCL's network. Suppliers and customers of SCLs are willing to accept the waivers as they intend to build up a dependence relationship in their favor [53]. The higher the dependency in favor of the SCL, the more willing SCL suppliers are to accept a discount on their sales and the more willing SCL customers are to accept a substantial price premium. Thus, future supply chain investigations should stress much more the "concession motivations" of suppliers and customers being part of a SCL network.

\subsection{Two-sided Financial Characteristics of SCL Networks}

Surprisingly, the present study shows multilateral implications for suppliers and customers of SCL firms. The results suggest benefits for suppliers and customers of SCLs in terms of liquidity and activity ratios but also indicate that SCLs to some extent exploit their partners' profitability through the power the SCLs possess.

The multilateral implications for suppliers and customers suggest two-sided behavior by SCL firms with their affiliated supply chain partners. Based on Emerson [94], Gulati and Sytch [28] state the importance of considering two different dimensions when analyzing interdependence: asymmetric dependency (in the logic of power) and joint dependency (in the logic of embeddedness). The present results seem to confirm these interdependencies. It can clearly be seen that in both relationships (suppliers-SCLs and SCLs-customers), there is an asymmetric dependence, where suppliers and customers are much more dependent on their SCLs than vice versa. A joint dependency in these relationships can only be suggested as an explanation for the two-sided findings and the fact that suppliers and customers also benefit from their relationships with SCLs. Brányi and Józsa [7] came to a very similar conclusion: Cooperation can also exist when a firm has power.

According to our discussion, we formulate the following proposition: 
Proposition 4. Within an SCL's network, SCL firms, on one hand, dominate their suppliers and customers, but, on the other hand, they also depend on these affiliated supply chain partners.

By analyzing concentrated three-firm supply chains, Lanier et al. [24] showed that in such constellations, although the profitability is principally earned by downstream members in the supply chain, the CCCs are earned across the supply chain. One reason for the better profitability of downstream members was that the power in a chain is derived from the relationship with the ultimate consumer and the position as the manager of the consumption point [95]. The present study results are to some extent in contrast with these observations, considering that most of the profitability is captured from the dominant SCLs in the middle of the chain. It could be suggested that SCLs, with their powerful position, steer and manage the supply chain's financial performance. On one hand, SCLs seem to allow their partners to have better liquidity and resource utilization conditions. On the other hand, SCLs exploit their partners when it comes to profitability. Figure 4 summarizes the main results.

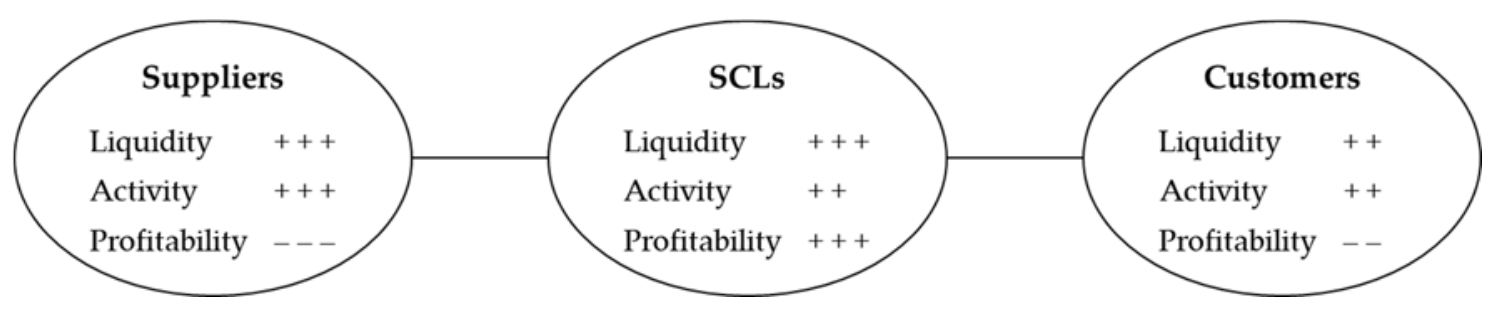

Figure 4. Financial performance distribution in the SCL networks. +++ very strong positive correlation; ++ strong positive correlation;. - - - very strong negative correlation; - - strong negative correlation.

\subsection{Financial Dependence of Suppliers in SCL Networks}

Until now, the discussion has been focused on the fact that suppliers and customers gain similar financial advantages and disadvantages by doing business with SCLs. It was highlighted that the SCLs are the dominant firms that gain the most from the supply chain's financial performance. Now, the discussion shifts to a closer look at the firms' respective positions in the chain and the dependency of suppliers and customers of SCLs.

Looking more closely at the supply chain position of the firms in the three samples, whereas most SCLs (70.6\%) and suppliers (85.7\%) are manufacturers and so on, instead of one step before the point of consumption, the majority of customers $(40.5 \%)$ are retailers and have direct contact with end consumers. Lanier et al. [24] showed that downstream members have more profitability benefits. This contradicts the present study results on two points. First, the power in the suppliers-SCL and SCL-customers constellation lies in the middle, where SCLs have a dominant position and gain most from the profitability in the chain. Second, the customers, who are the most downstream members in this triad and are closest to the final consumer, do not display superior profitability ratios.

We already addressed that suppliers' results, compared to the customers' results, are much more statistically significant and clear. Now, these results will be deepened. In order to analyze the dependence of suppliers and customers of SCLs, the sample sizes (see Appendix B) and the relationship strength are briefly examined.

Looking at the sample sizes, in terms of market capitalization and employee numbers, all SCL firms are at least large cap, and the majority of the firms (70.6\%) have more than 100,000 employees. While the suppliers' sample consists mainly of mid- $(39.3 \%)$ and large $(42.9 \%)$ caps, with only $21.4 \%$ of the firms that have more than 100,000 employees, $76.1 \%$ of the customer firms are at least large caps, and $61.9 \%$ have more than 100,000 employees. The SCLs are among the biggest and most powerful firms in the world, and the customer firms are, on average, bigger than the supplier companies. We suggest a higher dependency of suppliers on SCLs than customers. Kim and Henderson [20] found differences between suppliers' and customers' resource dependency. Whereas the benefit of customer dependency for focal firms decreases after a while, the supplier dependency increases above this 
margin. In addition, if these results refer to the profitability of focal firms, they show that customers are less dependent on focal firms, which explains the decrease in performance. What is interesting here, is that the findings suggest that an increase in dependency is not only negative for supply chain members of SCLs but can also be positively correlated to financial performance. The suppliers' results show better and more significant liquidity and activity ratios than customers'.

This discussion leads to the last proposition:

Proposition 5. Within an SCL's network, suppliers benefit more than customers (leading to superior liquidity and activity ratios) but are also more exploited (leading to inferior profitability ratios).

Despite the clear results and the coherent proposition, several important points could not be answered:

- Did the financial success, or rather failure, of the suppliers and customers already exist before they became members of the SCL's network, or did this occur afterwards?

- If the first of these applies, could this-the specific selection of suppliers respectively customers with superior liquidity and activity ratios respectively inferior profitability ratios-be a further success factor of SCLs?

- Do the derived results also refer to smaller suppliers and customers of the SCL? In the present examination, only the biggest partners of the supply chain are examined.

- The findings will probably not be transferable to the entire network and every single small player of the SCL. In that case, it would be interesting to know which type of supplier and customer is affected by this. Besides the company size according to COGS (suppliers) or revenue (customers), the criticality of the players could be of importance.

- Besides the examined supply chain constellations, do further SCL networks exist, onto which the results could be transferred? Is it the criteria of the Gartner Supply Chain Top 25 rankings or other characteristics, which distinguish these SCL networks?

- Which circumstances have to be met in order for not only the SCLs but also the suppliers and the customer firms of the network to have superior profitability ratios?

\section{Conclusions and Outlook}

\subsection{Summary}

The purpose of this study was to provide a general answer to the question: Why should companies be part of an SCL's network? Specifically, the study sought to analyze the financial spillover effect in supply chain networks of SCL companies. To the best of our knowledge, this study is the first attempt to explore this topic in a comprehensive way. In answering the research question and investigating suppliers-SCL and SCL-customer constellations, the liquidity, activity and profitability ratios of three central samples were tested and compared with control groups.

The results show a very clear picture. First, the SCL results confirmed the financial superiority of leader firms in SCM (according to Greer and Theuri [15]). Second, the supplier and customer results gave some interesting insights. Both showed superior liquidity and activity ratios and inferior profitability ratios. The superior liquidity ratios in SCL networks can be explained by the redistribution thesis [86,87]; a reason for superior activity ratios is the knowledge transfer thesis [54,55]. An explanation of the inferior profitability ratios ("profitability waiver") is the strategic choice of the suppliers and customers being part of the SCL's network [58], together with an asymmetric power and dependency balance in favor of the SCL [28]. The more dependent party (suppliers) is more significantly affected in terms of positive and negative financial performance implications, which is in line with the evidence found by Lanier et al. [24]. Finally, it can be concluded that companies should participate in an SCL's network because of the positive implications in terms of their liquidity and resource utilization ratios. However, companies should not underestimate the potential implications for profitability. 


\subsection{Contribution to Theory and Practice}

The present results make some contributions to theory and practice. First, the study contributes to the SCM and industrial networks' literature by providing deeper insights into supplier-SCL and SCL-customer relationships. Based on the literature on SCM excellence [10] and that SCLs are typically associated with superior financial performance ratios [15], the present study extends the focus by analyzing the suppliers and customers of these leader companies. The results are controversial and suggest two-sided behavior by SCLs toward their business partners. More attention must be spent while operationalizing the financial benefits of supply chain relationships, precisely differing between effects on liquidity, activity or profitability ratios.

Second, the present results have some implications for practice, particularly for managers of companies that sell or buy products from SCL firms. The financial advantages and disadvantages (spillover effects) of participating in an SCL's network are now more appropriate to predict. This study showed the financial performance distributions within suppliers-SCL and SCL-customer constellations. The knowledge that, in such a constellation, suppliers and customers can draw benefits in terms of liquidity and activity but lose in terms of profitability ratios, can help SCLs' business partners better plan and assess their relationship. It was shown that suppliers, in general, have a higher dependency in this specific supply chain, and are more strongly affected by the positive and negative factors. These are important insights that could help companies to better negotiate their position in this specific supply chain.

\subsection{Limitations}

Although the present study contributes in a significant way to better understanding the financial performance implications for suppliers and customers of SCLs, several limitations should be noted. First, because of the selected study design, the findings display correlations between the financial performance of suppliers and customers of SCLs, without providing information about the causalities. During the discussion, some suggestions about possible causalities were put forward, based on existing literature. Second, the analysis focused on large, listed companies. In addition, through the selection of the control sample, a threshold of USD 2 billion market capitalization was set. Therefore, smaller companies were explicitly excluded from the analysis. Third, only the five largest suppliers and customers of SCLs were investigated. For example, Apple, one of the analyzed SCLs, has more than 200 suppliers [96] (p. 30). Fourth, only short-term and accounting-based ratios were analyzed. To analyze financial performance more comprehensively, the study could be extended by incorporating solvency and valuation ratios [46].

\subsection{Future Research}

Although the analysis highlighted interesting correlations between SCLs' supplier and customer financial performance ratios, of interest for further studies is revealing the causalities behind these correlations. Topics such as "social capital" [27], or the relatedness and interrelations of suppliers in triads [97], could not be deepened because the link was missing in the study methodology. However, these studies are important when looking at relationships between business partners across the supply chain. For future research, it may be interesting to investigate causalities in a social capital context.

Further, the results of this study are controversial, calling into question the role of SCL firms. What does it mean to be a leader in a supply chain? The findings showed that suppliers and customers can benefit in their liquidity and activity from the relationship, but they can also lose profitability. Thus, two-sided behavior by SCLs could be suggested. As Christopher [8] stated, vanguard firms understand that relocating costs up- and downstream are not worthwhile, because the costs always ultimately mirror the final product. Based on the present results, this does not seem to be of much concern to an SCL firm. Future studies could tackle this issue and analyze whether there is potential for SCLs to provide profitability benefits to selected suppliers and customers. 
Finally, the results could also be extended in the context of supply chain finance (SCF) and supply chain costing. As the SCF definition has a link to liquidity [98,99] and supply chain costing to activity $[100,101]$, it could be relevant to the present findings. Although this study showed benefit distributions in liquidity and activity ratios, it will be interesting for future studies to more closely analyze profitability with SCF and supply chain costing together. It would be exciting to understand what cooperation in both areas between supply chain members in the presence of leader firms looks like.

Author Contributions: Supervision and re-writing, E.H.; writing—original draft, Y.S. All authors have read and agreed to the published version of the manuscript.

Funding: This research received no external funding.

Conflicts of Interest: The authors declare no conflict of interest.

\section{Appendix A. Company Names and According SIC Code}

Table A1. SCL firms and four-digit SIC codes (after adjustments).

\begin{tabular}{cc}
\hline Company Name & SIC Code \\
\hline Nestle SA & 2000 \\
\hline Coca-Cola Co/The & 2086 \\
\hline PepsiCo Inc & 2086 \\
\hline Johnson \& Johnson & 2834 \\
\hline Procter \& Gamble Co/The & 2840 \\
\hline Colgate-Palmolive Co & 2844 \\
\hline NIKE Inc & 3021 \\
\hline Apple Inc & 3571 \\
\hline Cisco Systems Inc & 3577 \\
\hline Intel Corp & 3674 \\
\hline Samsung Electronics Co Ltd & 3674 \\
\hline 3M Co & 3841 \\
\hline Unilever NV & 5140 \\
\hline Wal-Mart Stores Inc & 5331 \\
\hline Industria de Diseno Textil SA & 5600 \\
\hline McDonald's Corp & 5812 \\
\hline Amazon.com Inc & 5961 \\
\hline
\end{tabular}

Table A2. Supplier firms and four-digit SIC codes (after adjustments).

\begin{tabular}{cccc}
\hline Company Name & SIC Code & Company Name & SIC Code \\
\hline Nestle SA & 2000 & Hewlett Packard Enterprise Co & 3570 \\
\hline Wilmar International Ltd & 2070 & HP Inc & 3570 \\
\hline Dr Pepper Snapple Group Inc & 2086 & Lenovo Group Ltd & 3570 \\
\hline Monster Beverage Corp & 2086 & Apple Inc & 3571 \\
\hline PepsiCo Inc & 2086 & Sony Corp & 3600 \\
\hline McCormick \& Co Inc/MD & 2090 & QUALCOMM Inc & 3663 \\
\hline Hansae Co Ltd & 2300 & AU Optronics Corp & 3674 \\
\hline Pan-Pacific Co Ltd & 2300 & Celestica Inc & 3674 \\
\hline International Paper Co & 2621 & Flextronics International Ltd & 3674 \\
\hline WestRock MWV LLC & 2621 & Hon Hai Precision Industry Co Ltd & 3674 \\
\hline Amcor Ltd/Australia & 2670 & Ibiden Co Ltd & 3674 \\
\hline
\end{tabular}


Table A2. Cont.

\begin{tabular}{cccc}
\hline Company Name & SIC Code & Company Name & SIC Code \\
\hline Avery Dennison Corp & 2670 & Jabil Circuit Inc & 3674 \\
\hline Bemis Co Inc & 2670 & Japan Display Inc & 3674 \\
\hline CCL Industries Inc & 2670 & Micron Technology Inc & 3674 \\
\hline Huhtamaki OYJ & 2670 & Samsung Electronics Co Ltd & 3674 \\
\hline Johnson Matthey PLC & 2800 & Shinko Electric Industries Co Ltd & 3674 \\
\hline Koninklijke DSM NV & 2800 & Viavi Solutions Inc & 3674 \\
\hline Berry Plastics Group Inc & 2820 & BOE Technology Group Co Ltd & 3679 \\
\hline Indorama Ventures PCL & 2820 & LG Display Co Ltd & 3679 \\
\hline Alkermes PLC & 2834 & Honeywell International Inc & 3714 \\
\hline Pharmacyclics Inc & 2834 & Union Pacific Corp & 4011 \\
\hline Procter \& Gamble Co/The & 2840 & United Parcel Service Inc & 4210 \\
\hline PPG Industries Inc & 2851 & XPO CNW Inc & 4213 \\
\hline BASF SE & 2860 & Ingram Micro Inc & 5045 \\
\hline Braskem SA & 2860 & Sun-Wa Technos Corp & 5045 \\
\hline Givaudan SA & 2860 & Pegatron Corp & 5065 \\
\hline International Flavors \& Fragrances Inc & 2860 & Berkshire Hathaway Inc & 6331 \\
\hline EI du Pont de Nemours \& Co & 2870 & Microsoft Corp & 7372 \\
\hline
\end{tabular}

Table A3. Customer firms and four-digit SIC codes (after adjustments).

\begin{tabular}{|c|c|c|c|}
\hline Company Name & SIC Code & Company Name & SIC Code \\
\hline Coca-Cola East Japan Co Ltd & 2086 & Verizon Communications Inc & 4813 \\
\hline Coca-Cola Enterprises Inc & 2086 & Avnet Inc & 5065 \\
\hline Coca-Cola Femsa SAB de CV & 2086 & WPG Holdings Ltd & 5065 \\
\hline Coca-Cola HBC AG & 2086 & Unilever NV & 5140 \\
\hline Allergan plc & 2834 & Dollar General Corp & 5331 \\
\hline Belle International Holdings Ltd & 3021 & Target Corp & 5331 \\
\hline HP Inc & 3570 & Wal-Mart Stores Inc & 5331 \\
\hline Lenovo Group Ltd & 3570 & Aeon Co Ltd & 5399 \\
\hline Apple Inc & 3571 & Carrefour SA & 5399 \\
\hline General Electric Co & 3600 & Costco Wholesale Corp & 5399 \\
\hline Hon Hai Precision Industry Co Ltd & 3674 & Tesco PLC & 5399 \\
\hline Texas Instruments Inc & 3674 & Auchan Holding SA & 5411 \\
\hline Ford Motor Co & 3711 & Casino Guichard Perrachon SA & 5411 \\
\hline Honda Motor Co Ltd & 3711 & Koninklijke Ahold NV & 5411 \\
\hline Toyota Motor Corp & 3711 & Kroger Co/The & 5411 \\
\hline Volkswagen AG & 3711 & Aramark & 5812 \\
\hline Rogers Communications Inc & 4812 & CVS Health Corp & 5912 \\
\hline T-Mobile US Inc & 4812 & Rite Aid Corp & 5912 \\
\hline Telefonica SA & 4812 & Dick's Sporting Goods Inc & 5940 \\
\hline AT\&T Inc & 4813 & Sports Direct International PLC & 5940 \\
\hline Deutsche Telekom AG & 4813 & Amazon.com Inc & 5961 \\
\hline
\end{tabular}




\section{Appendix B. Central Samples' Descriptive Data}

Table A4. Distribution of central sample firms per country.

\begin{tabular}{|c|c|c|c|c|c|c|}
\hline \multirow{2}{*}{ Country } & \multicolumn{2}{|c|}{ SCLs } & \multicolumn{2}{|c|}{ Suppliers } & \multicolumn{2}{|c|}{ Customers } \\
\hline & $\mathbf{N}$ & $\%$ & $\mathbf{N}$ & $\%$ & $\mathbf{N}$ & $\%$ \\
\hline AU & - & - & 1 & $1.8 \%$ & - & - \\
\hline $\mathrm{BR}$ & - & - & 1 & $1.8 \%$ & - & - \\
\hline CA & - & - & 2 & $3.6 \%$ & 1 & $2.4 \%$ \\
\hline $\mathrm{CH}$ & 1 & $5.9 \%$ & 2 & $3.6 \%$ & 1 & $2.4 \%$ \\
\hline $\mathrm{CN}$ & - & - & 2 & $3.6 \%$ & 2 & $4.8 \%$ \\
\hline $\mathrm{DE}$ & - & - & 1 & $1.8 \%$ & 2 & $4.8 \%$ \\
\hline ES & 1 & $5.9 \%$ & - & - & 1 & $2.4 \%$ \\
\hline FI & - & - & 1 & $1.8 \%$ & - & - \\
\hline FR & - & - & - & - & 3 & $7.1 \%$ \\
\hline GB & 1 & $5.9 \%$ & 1 & $1.8 \%$ & 4 & $9.5 \%$ \\
\hline IE & - & - & 1 & $1.8 \%$ & - & - \\
\hline JP & - & - & 5 & $8.9 \%$ & 4 & $9.5 \%$ \\
\hline $\mathrm{KR}$ & 1 & $5.9 \%$ & 4 & $7.1 \%$ & - & - \\
\hline MX & - & - & - & - & 1 & $2.4 \%$ \\
\hline NL & - & - & 1 & $1.8 \%$ & 1 & $2.4 \%$ \\
\hline SG & - & - & 1 & $1.8 \%$ & - & - \\
\hline $\mathrm{TH}$ & - & - & 1 & $1.8 \%$ & - & - \\
\hline TW & - & - & 3 & $5.4 \%$ & 2 & $4.8 \%$ \\
\hline US & 13 & $76.5 \%$ & 29 & $51.8 \%$ & 20 & $47.6 \%$ \\
\hline
\end{tabular}

Table A5. Distribution of central sample firms per market capitalization category.

\begin{tabular}{ccccccc}
\hline \multirow{2}{*}{$\begin{array}{c}\text { Market } \\
\text { capitalization }\end{array}$} & \multicolumn{2}{c}{ SCLs } & \multicolumn{2}{c}{ Suppliers } & \multicolumn{2}{c}{ Customers } \\
\cline { 2 - 7 } & $\mathbf{N}$ & $\%$ & $\mathbf{N}$ & $\%$ & $\mathbf{N}$ & $\%$ \\
\hline Mega cap & 5 & $29.4 \%$ & 5 & $8.9 \%$ & 3 & $7.1 \%$ \\
\hline Large cap & 12 & $70.6 \%$ & 24 & $42.9 \%$ & 29 & $69.0 \%$ \\
\hline Mid cap & - & - & 22 & $39.3 \%$ & 6 & $14.3 \%$ \\
\hline Smal cap & - & - & 4 & $7.1 \%$ & 2 & $4.8 \%$ \\
\hline n/a & - & - & 1 & $1.8 \%$ & 2 & $4.8 \%$ \\
\hline
\end{tabular}

Table A6. Distribution of central sample firms per employee category.

\begin{tabular}{ccccccc}
\hline \multirow{2}{*}{ Employees } & \multicolumn{2}{c}{ SCLs } & \multicolumn{2}{c}{ Suppliers } & \multicolumn{2}{c}{ Customers } \\
\cline { 2 - 7 } & $\mathbf{N}$ & $\%$ & $\mathbf{N}$ & $\%$ & $\mathbf{N}$ & $\%$ \\
\hline$>100 \mathrm{k}$ & 12 & $70.6 \%$ & 12 & $21.4 \%$ & 26 & $61.9 \%$ \\
\hline $10 \mathrm{k}-100 \mathrm{k}$ & 5 & $29.4 \%$ & 26 & $46.4 \%$ & 12 & $28.6 \%$ \\
\hline$<10 \mathrm{k}$ & - & - & 11 & $19.6 \%$ & 2 & $4.8 \%$ \\
\hline n/a & - & - & 7 & $12.5 \%$ & 2 & $4.8 \%$ \\
\hline
\end{tabular}




\section{References}

1. Wilkinson, I.; Young, L. On cooperating: Firms, relations and networks. J. Bus. Res. 2002, 55, $123-132$. [CrossRef]

2. Cannon, J.P.; Perreault, W.D. Buyer-seller relationships in business markets. J. Mark. Res. 1999, 36, 439-460.

3. Doney, P.M.; Cannon, J.P. An examination of the nature of trust in buyer-seller relationships. J. Mark. 1997, 61, 35-51.

4. Kalwani, M.U.; Narayandas, N. Long-term manufacturer-supplier relationships: Do they pay off for supplier firms? J. Mark. 1995, 59, 1-16. [CrossRef]

5. Monczka, R.M.; Petersen, K.J.; Handfield, R.B.; Ragatz, G.L. Success factors in strategic supplier alliances: The buying company perspective. Decis. Sci. 1998, 29, 553-577. [CrossRef]

6. Rokkan, A.I.; Heidi, J.B.; Wathne, K.H. Specific investments in marketing relationships: Expropriation and bonding effects. J. Mark. Res. 2003, 40, 210-224. [CrossRef]

7. Brányi, T.; Józsa, L. Power of companies in supply chains and their effect on network development. J. Econ. Manag. 2015, 19, 221-239.

8. Christopher, M. Logistics and Supply Chain Management, 4th ed.; Pearson Education: London, UK, 2011.

9. Ketchen, D.J.; Giunipero, L.C. The intersection of strategic management and supply chain management. Ind. Mark. Manag. 2004, 33, 51-56. [CrossRef]

10. Shi, M.; Yu, W. Supply chain management and financial performance: Literature review and future directions. Int. J. Oper. Prod. Manag. 2013, 33, 1283-1317. [CrossRef]

11. Ellinger, A.E.; Natarajarathinam, M.; Adams, F.G.; Gray, J.B.; Hofman, D.; O'Marah, K. Supply chain management competency and firm financial success. J. Bus. Logist. 2011, 32, 214-226. [CrossRef]

12. Ireland, R.D.; Webb, J.W. A multi-theoretic perspective on trust and power in strategic supply chains. J. Oper. Manag. 2007, 25, 482-497. [CrossRef]

13. Vickery, S.K.; Jayaram, J.; Droge, C.; Calantone, R. The effects of an integrative supply chain strategy on customer service and financial performance: An analysis of direct vs. indirect relationships. J. Oper. Manag. 2003, 21, 523-539. [CrossRef]

14. D'Avanzo, R.; von Lewinski, H.; Van Wassenhove, L.N. The link between supply chain and financial performance. Supply Chain Manag. Rev. 2003, 7, 40-47.

15. Greer, B.M.; Theuri, P. Linking supply chain management superiority to multifaceted firm financial performance. J. Supply Chain Manag. 2012, 48, 97-106. [CrossRef]

16. Presutti, W.D.; Mawhinney, J.R. The supply chain-finance link. Supply Chain Manag. Rev. 2007, 11, 32-38.

17. Swink, M.L.; Golecha, R.; Richardson, T. Does supply chain excellence really pay off? Supply Chain Manag. Rev. 2010, 14, 14-21.

18. Mitra, S.; Singhal, V. Supply chain integration and shareholder value: Evidence from consortium based industry exchanges. J. Oper. Manag. 2008, 26, 96-114. [CrossRef]

19. Crook, T.R.; Combs, J.G. Sources and consequences of bargaining power in supply chains. J. Oper. Manag. 2007, 25, 546-555. [CrossRef]

20. Kim, Y.H.; Henderson, D. Financial benefits and risks of dependency in triadic supply chain relationships. J. Oper. Manag. 2015, 36, 115-129. [CrossRef]

21. Gosman, M.L.; Kohlbeck, M.J. Effects of the existence and identity of major customers on supplier profitability: Is Wal-Mart different? J. Manag. Account. Res. 2009, 21, 179-201. [CrossRef]

22. Kelly, T.; Gosman, M.L. Increased buyer concentration and its effects on profitability in the manufacturing sector. Rev. Ind. Organ. 2000, 17, 41-59. [CrossRef]

23. Kim, Y.H.; Wemmerlöv, U. Does a supplier's operational competence translate into financial performance? An empirical analysis of supplier-customer relationships. Decis. Sci. 2015, 46, 101-134. [CrossRef]

24. Lanier, D.; Wempe, W.F.; Zacharia, Z.G. Concentrated supply chain membership and financial performance: Chain- and firm-level perspectives. J. Oper. Manag. 2010, 28, 1-16. [CrossRef]

25. Patatoukas, P.N. Customer-base concentration: Implications for firm performance and capital markets. Account. Rev. 2012, 87, 363-392. [CrossRef]

26. Carey, S.; Lawson, B.; Krause, D.R. Social capital configuration, legal bonds and performance in buyer-supplier relationships. J. Oper. Manag. 2011, 29, 277-288. [CrossRef] 
27. Villena, V.H.; Revilla, E.; Choi, T.Y. The dark side of buyer-supplier relationships: A social capital perspective. J. Oper. Manag. 2011, 29, 561-576. [CrossRef]

28. Gulati, R.; Sytch, M. Dependence asymmetry and joint dependence in interorganizational relationships: Effects of embeddedness on a manufacturer's performance in procurement relationships. Adm. Sci. Q. 2007, 52, 32-69. [CrossRef]

29. Krause, D.R.; Handfield, R.B.; Tyler, B.B. The relationships between supplier development, commitment, social capital accumulation and performance improvement. J. Oper. Manag. 2007, 25, 528-545. [CrossRef]

30. Lawson, B.; Tyler, B.B.; Cousins, P.D. Antecedents and consequences of social capital on buyer performance improvement. J. Oper. Manag. 2008, 26, 446-460. [CrossRef]

31. Sanders, N.R. IT alignment in supply chain relationships: A study of supplier benefits. J. Supply Chain Manag. 2005, 41, 4-13. [CrossRef]

32. Rabinovich, E.; Cheon, S. Expanding horizons and deepening understanding via the use of secondary data sources. J. Bus. Logist. 2011, 32, 303-316. [CrossRef]

33. Busse, C. A procedure for secondary data analysis: Innovation by logistics service providers. J. Supply Chain Manag. 2010, 46, 44-58. [CrossRef]

34. Johnson, M.; Templar, S. The relationships between supply chain and firm performance. Int. J. Phys. Distrib. Logist. Manag. 2011, 41, 88-103. [CrossRef]

35. Pricewaterhouse Coopers LLP. Next-Generation Supply Chains. Efficient, Fast and Tailored. 2013. Available online: http://www.pwc.com/gx/en/services/advisory/consulting/supply-chain/supply-chain-survey.html (accessed on 10 April 2016).

36. Deloitte Consulting LLP Supply Chain Leadership. Distinctive Approaches to Innovation, Collaboration, and Talent Alignment. 2014. Available online: https://www2.deloitte.com/us/en/pages/operations/articles/su pply-chain-leadership.html (accessed on 19 September 2016).

37. Brandenburg, M. Quantitative Models for Value-Based Supply Chain Management; Springer: Berlin/Heidelberg, Germany, 2013.

38. Brandenburg, M. Supply chain efficiency, value creation and the economic crisis-An empirical assessment of the European automotive industry 2002-2010. Int. J. Prod. Econ. 2016, 171, 321-335. [CrossRef]

39. Rostami, A.; Rostami, A.A.A.; Jalali, S.; Nazemi, A.R. Relation between supply chain efficiency and supply chain finance. Int. Res. J. Appl. Basic Sci. 2013, 4, 416-423.

40. Christopher, M. Logistics and Supply Chain Management. Strategies for Reducing Costs and Improving Services, 1st ed.; Pitman Publishing: London, UK, 1992.

41. Christopher, M.; Gattorna, J. Supply chain cost management and value-based pricing. Ind. Mark. Manag. 2005, 34, 115-121. [CrossRef]

42. Walters, D. Demand chain effectiveness-Supply chain efficiencies. A role for enterprise information management. J. Enterp. Inf. Manag. 2006, 19, 246-261. [CrossRef]

43. Lo, C.K.Y.; Yeung, A.C.L.; Cheng, T.C.E. Meta-standards, financial performance and senior executive compensation in China: An institutional perspective. Int. J. Prod. Econ. 2011, 129, 119-126. [CrossRef]

44. Farris II, M.T.; Hutchison, P.D. Cash-to-cash: The new supply chain management metric. Int. J. Phys. Distrib. Logist. Manag. 2002, 32, 288-298. [CrossRef]

45. Farris II, M.T.; Hutchison, P.D. Measuring Cash-to-Cash Performance. Int. J. Logist. Manag. 2003, 14, 83-92. [CrossRef]

46. Henry, E.; Robinson, T.R.; van Greuning, J.H. Financial Analysis Techniques. In Financial Reporting and Analysis; CFA Institute: Charlottesville, VA, USA, 2012; pp. 299-369.

47. Wagner, S.M.; Grosse-Ruyken, P.T.; Erhun, F. The link between supply chain fit and financial performance of the firm. J. Oper. Manag. 2012, 30, 340-353. [CrossRef]

48. Craighead, C.W.; Blackhurst, J.; Rungtusanatham, M.J.; Handfield, R.B. The severity of supply chain disruptions: Design characteristics and mitigation capabilities. Decis. Sci. 2007, 38, 131-156. [CrossRef]

49. Hendricks, K.B.; Singhal, V.R. Association between supply chain glitches and operating performance. Manag. Sci. 2005, 51, 695-711. [CrossRef]

50. Hendricks, K.B.; Singhal, V.R. Demand-supply mismatches and stock market reaction: Evidence from excess inventory announcements. Manuf. Serv. Oper. Manag. 2009, 11, 509-524. [CrossRef]

51. Gartner. Gartner Supply Chain Top 25. 2016. Available online: http://www.gartner.com/technology/supplychain/top25.jsp (accessed on 3 August 2016). 
52. McCarter, M.W.; Northcraft, G.B. Happy together?: Insights and implications of viewing managed supply chains as a social dilemma. J. Oper. Manag. 2007, 25, 498-511. [CrossRef]

53. Morgan, N.A.; Kaleka, A.; Gooner, R.A. Focal supplier opportunism in supermarket retailer category management. J. Oper. Manag. 2007, 25, 512-527. [CrossRef]

54. Blome, C.; Schoenherr, T.; Eckstein, D. The impact of knowledge transfer and complexity on supply chain flexibility: A knowledge-based view. Int. J. Prod. Econ. 2014, 147, 307-316. [CrossRef]

55. Hult, G.T.M.; Ketchen, D.J.; Cavusgil, S.T.; Calantone, R.J. Knowledge as a strategic resource in supply chains. J. Oper. Manag. 2006, 24, 458-475. [CrossRef]

56. Doyle, S.A.; Moore, C.M.; Morgan, L. Supplier management in fast moving fashion retailing. J. Fash. Mark. Manag. 2006, 10, 272-281. [CrossRef]

57. Hamister, J.W. Supply chain management practices in small retailers. Int. J. Retail; Distrib. Manag. 2012, 40, 427-450. [CrossRef]

58. Ketchen, D.J.; Hult, G.T.M. Bridging organization theory and supply chain management: The case of best value supply chains. J. Oper. Manag. 2007, 25, 573-580. [CrossRef]

59. Tan, K.-C.; Kannan, V.R.; Handfield, R.B.; Ghosh, S. Supply chain management: An empirical study of its impact on performance. Int. J. Oper. Prod. Manag. 1999, 19, 1034-1052. [CrossRef]

60. Carr, A.S.; Pearson, J.N. Strategically managed buyer-supplier relationships and performance outcomes. J. Oper. Manag. 1999, 17, 497-519. [CrossRef]

61. Corsten, D.; Kumar, N. Do suppliers benefit from collaborative relationships with large retailers? An empirical investigation of efficient consumer response adoption. J. Mark. 2005, 69, 80-94. [CrossRef]

62. Gosman, M.L.; Kelly, T. Big customers and their suppliers: A case examining changes in business relationships and their financial effects. Issues Account. Educ. 2002, 17, 41-56. [CrossRef]

63. Duffy, R.; Fearne, A. The impact of supply chain partnerships on supplier performance. Int. J. Logist. Manag. 2004, 15, 57-72. [CrossRef]

64. Franks, J.R.; Nyborg, K.G. Control rights, debt structure, and the loss of private benefits: The case of the UK insolvency code. Rev. Financ. Stud. 1996, 9, 1165-1210. [CrossRef]

65. Kovács, G.; Spens, K.M. Abductive reasoning in logistics research. Int. J. Phys. Distrib. Logist. Manag. 2005, 35, 132-144. [CrossRef]

66. Coe, T.S. Using the Bloomberg professional system for finance classes. J. Financ. Educ. 2007, 33, 48-62.

67. Clifford, S.; Creswell, J. At Bloomberg, Modest Strategy to Rule the World. The New York Times. 4 November 2009. Available online: http://www.nytimes.com/2009/11/15/business/media/15bloom.html (accessed on 25 June 2016).

68. Lei, A.Y.C.; Li, H. Using Bloomberg terminals in a security analysis and portfolio management course. J. Econ. Financ. Educ. 2012, 11, 17-33. [CrossRef]

69. Standard; Poor's \& Standard; Poor's Compustat. Products \& Services for the Academic Community. Available online: http://fccee.ugr.es/pages/facultad/vicedecanatos/vicedecanato-de-investigacion-y-posgra do/documentos/bases-de-datos/compustat-for-academics/ (accessed on 22 March 2016).

70. Bharadwaj, A.S. A resource-based perspective on information technology capability and firm performance: An empirical investigation. MIS Q. 2000, 24, 169-196. [CrossRef]

71. Santhanam, R.; Hartono, E. Issues in linking information technology capability to firm performance. Mis $Q$. 2003, 27, 125-153. [CrossRef]

72. Aronow, S.; Burkett, M.; Romano, J.; Nilles, K. The 2016 supply chain top 25: Lessons from leaders. Supply Chain Manag. Rev. 2016, 20, 10-21.

73. Gilmore, D. Understanding the 2015 Gartner Top 25 Supply Chain Rankings. 2015. Available online: http://www.scdigest.com/assets/FirstThoughts/15-05-21.php (accessed on 25 May 2016).

74. Aronow, S.; Burkett, M.; Romano, J.; Nilles, K. 2015 supply chain top 25: The art and science. Supply Chain Manag. Rev. 2015, 19, 14-22.

75. Gartner. Our methodology: How Gartner selects the top 25. Supply Chain Manag. Rev. 2015, 19, 23.

76. Aronow, S.; Hofman, D.; Burkett, M.; Romano, J.; Nilles, K. The 2014 supply chain top 25: Leading the decade. Supply Chain Manag. Rev. 2014, 18, 8-17.

77. Hofman, D. The top 25 supply chains: Leadership in action. Supply Chain Manag. Rev. 2011, 15, 8-15.

78. Hofman, D.; Aronow, S. The supply chain top 25: Raising the bar. Supply Chain Manag. Rev. 2012, 16, 10-19. 
79. Hofman, D.; Aronow, S.; Nilles, K. The 2013 supply chain: Learning from leaders. Supply Chain Manag. Rev. 2013, 17, 12-21.

80. Poston, R.; Grabski, S. Financial impacts of enterprise resource planning implementations. Int. J. Account. Inf. Syst. 2001, 2, 271-294. [CrossRef]

81. Stewart, G. Supply chain performance benchmarking study reveals keys to supply chain excellence. Logist. Inf. Manag. 1995, 8, 38-44. [CrossRef]

82. Weiers, R.M. Introductory Business Statistics, 7th ed.; Cengage Learning: Boston, MA, USA, 2011.

83. Conover, W.J. Practical Nonparametric Statistics; John Wiley and Sons: Hoboken, NJ, USA, 1999.

84. Hofmann, E.; Kotzab, H. A supply chain-oriented approach of working capital management. J. Bus. Logist. 2010, 31, 305-330. [CrossRef]

85. Meltzer, A.H. Mercantile credit, monetary policy, and size of firms. Rev. Econ. Stat. 1960, 429-437. [CrossRef]

86. Petersen, M.A.; Rajan, R.G. Trade credit: Theories and evidence. Rev. Financ. Stud. 1997, 10, 661-691. [CrossRef]

87. Cuñat, V. Trade credit: Suppliers as debt collectors and insurance providers. Rev. Financ. Stud. 2007, 20, 491-527. [CrossRef]

88. Long, M.S.; Malitz, I.B.; Ravid, S.A. Trade credit, quality guarantees, and product marketability. Financ. Manag. 1993, 22, 117-127. [CrossRef]

89. Ng, C.K.; Smith, J.K.; Smith, R.L. Evidence on the determinants of credit terms used in interfirm trade. J. Financ. 1999, 54, 1109-1129. [CrossRef]

90. Bianco, A.; Zellner, W. Is Wal-Mart too powerful? Bus. Week 2003, 3852, 100-110.

91. Cannon, J.P.; Doney, P.M.; Mullen, M.R.; Petersen, K.J. Building long-term orientation in buyer-supplier relationships: The moderating role of culture. J. Oper. Manag. 2010, 28, 506-521. [CrossRef]

92. Cao, M.; Zhang, Q. Supply chain collaboration: Impact on collaborative advantage and firm performance. J. Oper. Manag. 2011, 29, 163-180. [CrossRef]

93. Zeller, T.L.; Gillis, D.M. Achieving market excellence through quality: The case of Ford Motor. Bus. Horiz. 1995, 38, 23-31. [CrossRef]

94. Emerson, R.M. Power-dependence relations. Am. Sociol. Rev. 1962, 27, 31-41. [CrossRef]

95. Lambert, D.M.; Cooper, M.C.; Pagh, J.D. Supply chain management: Implementation issues and research opportunities. Int. J. Logist. Manag. 1998, 9, 1-19. [CrossRef]

96. Apple Inc. Supplier Responsibility 2016 Progress Report. 2016. Available online: http://www.apple.com/su pplier-responsibility/progress-report/ (accessed on 1 November 2016).

97. Choi, T.Y.; Wu, Z. Triads in supply networks: Theorizing buyer-supplier-supplier relationships. J. Supply Chain Manag. 2009, 45, 8-25. [CrossRef]

98. Hofmann, E.; Belin, O. Supply Chain Finance Solutions. Relevance-Propositions-Market Value; Springer: Berlin/Heidelberg, Germany, 2011. [CrossRef]

99. Wetzel, P.; Hofmann, E. Supply chain finance, financial constraints and corporate performance: An explorative network analysis and future research agenda. Int. J. Prod. Econ. 2019, 216, 364-383. [CrossRef]

100. Lin, B.; Collins, J.; Su, R.K. Supply chain costing: An activity-based perspective. Int. J. Phys. Distrib. Logist. Manag. 2001, 31, 702-713. [CrossRef]

101. Hofmann, E.; Bosshard, J. Supply chain management and activity-based costing. Int. J. Phys. Distrib. Logist. Manag. 2017, 47, 712-735. [CrossRef]

(C) 2020 by the authors. Licensee MDPI, Basel, Switzerland. This article is an open access article distributed under the terms and conditions of the Creative Commons Attribution (CC BY) license (http://creativecommons.org/licenses/by/4.0/). 